\title{
De waarde van MBO-4 opleidingen op de arbeidsmarkt
}

Citation for published version (APA):

Coenen, J. B., Ramaekers, G. W. M., \& van der Velden, R. K. W. (2012). De waarde van MBO-4 opleidingen op de arbeidsmarkt. Researchcentrum voor Onderwijs en Arbeidsmarkt, Faculteit der Economische Wetenschappen. ROA Reports No. 3 https://doi.org/10.26481/umarep.2012003

Document status and date:

Published: 01/01/2012

DOI:

10.26481/umarep.2012003

Document Version:

Publisher's PDF, also known as Version of record

\section{Please check the document version of this publication:}

- A submitted manuscript is the version of the article upon submission and before peer-review. There can be important differences between the submitted version and the official published version of record.

People interested in the research are advised to contact the author for the final version of the publication, or visit the DOI to the publisher's website.

- The final author version and the galley proof are versions of the publication after peer review.

- The final published version features the final layout of the paper including the volume, issue and page numbers.

Link to publication

\footnotetext{
General rights rights.

- You may freely distribute the URL identifying the publication in the public portal. please follow below link for the End User Agreement:

www.umlib.nl/taverne-license

Take down policy

If you believe that this document breaches copyright please contact us at:

repository@maastrichtuniversity.nl

providing details and we will investigate your claim.
}

Copyright and moral rights for the publications made accessible in the public portal are retained by the authors and/or other copyright owners and it is a condition of accessing publications that users recognise and abide by the legal requirements associated with these

- Users may download and print one copy of any publication from the public portal for the purpose of private study or research.

- You may not further distribute the material or use it for any profit-making activity or commercial gain

If the publication is distributed under the terms of Article $25 \mathrm{fa}$ of the Dutch Copyright Act, indicated by the "Taverne" license above, 


\section{De waarde van MBO-4 opleidingen op de arbeidsmarkt}

Johan Coenen

Ger Ramaekers

Rolf van der Velden

ROA-R-2012/3 


\section{Colofon}

(C) Researchcentrum voor Onderwijs en Arbeidsmarkt (ROA). Niets uit deze uitgave mag op enige manier worden verveelvoudigd zonder voorafgaande schriftelijke toestemming van de directeur van het ROA.

\section{Researchcentrum voor Onderwijs en Arbeidsmarkt}

School of Business and Economics

Maastricht University

\section{Vormgeving}

ROA secretariaat, Maastricht

ISBN: 978-90-532I-503-6 


\section{Inhoud}

Voorwoord

iii

1 Inleiding 1

1.1 Doel van het onderzoek 1

$\begin{array}{ll}1.2 \text { Opzet van het onderzoek } & 2 \\ 1.3 & 3\end{array}$

1.3 Leeswijzer 3

2 Theoretische achtergrond 5

3 Modellering 9

4 De relatie tussen opleidingsniveau, vaardigheden en arbeidsmarktsucces $\quad 15$

$\begin{array}{ll}4.1 \text { Vaardigheden } & 15\end{array}$

$\begin{array}{lll}4.2 \text { Kans op werk } & 21\end{array}$

4.3 Aansluiting tussen opleiding en werk 23

4.4 Beloning en carrièremogelijkheden in huidige functie 26

4.5 Andere arbeidsvoorwaarden 29

4.6 Oordelen over de opleiding als basis om te starten op de arbeidsmarkt en zich verder te ontwikkelen $\quad 32$

$\begin{array}{lll}4.7 & \text { De resultaten op een rij } & 34\end{array}$

$\begin{array}{lll}5 & \text { Conclusie } & 37\end{array}$

$\begin{array}{ll}\text { Literatuur } & 39\end{array}$ 



\section{Voorwoord}

De positie van de Nederlandse $\mathrm{MBO}-4$ opleidingen ten opzichte van andere beroepsopleidingen in Nederland en ten opzichte van vergelijkbare beroepsopleidingen in het buitenland is niet helemaal duidelijk. Als we kijken naar de relatief lange cumulatieve opleidingsduur, dan zou dit opleidingstype ook tot het tertiare onderwijs gerekend kunnen worden. Voor de bepaling van de positie en plaats van de $\mathrm{MBO}_{4} 4$ opleidingen gaat het echter niet alleen om de cumulatieve opleidingsduur, maar ook om het bereikte niveau van competenties. De vraag is dan of het niveau van competenties van $\mathrm{MBO}-4$ opleidingen vergelijkbaar is met het niveau van competenties bij bijvoorbeeld de korte opleidingen in het hoger onderwijs.

Op de achtergrond speelt de vraag of de Nederlandse $\mathrm{MBO}-4$ opleidingen tot het secundair beroepsonderwijs moeten worden gerekend of tot het (korte) hoger beroepsonderwijs. Een goed antwoord op deze vraag is van belang in het kader van de gewenste verhoging van de doorstroom naar het hoger onderwijs.

Om deze vraag te kunnen beantwoorden voert het Expertisecentrum Beroepsonderwijs (ECBO) onderzoek uit waarbij naast internationale systeemvergelijkingen ook een vergelijking wordt gemaakt van curricula. Daarnaast is het zinvol om een vergelijking te maken van de arbeidsmarktpositie van de $\mathrm{MBO}-4$ opleidingen en andere opleidingen. Het ECBO heeft het ROA verzocht dit laatste deel van het onderzoek uit te voeren.

Het onderzoek is uitgevoerd door drs. J. Coenen en drs. G. Ramaekers van het ROA. We bedanken drs. Tanja Traag van het CBS voor het uitvoeren van de analyses van het VOCL-cohort. De projectleiding was in handen van prof. R. van der Velden.

Maastricht, september 2012 



\section{Inleiding}

\subsection{Doel van het onderzoek}

Op verzoek van het Expertisecentrum Beroepsonderwijs (ECBO) heeft het ROA onderzoek verricht naar de positie en plaats van de $\mathrm{MBO}_{-4}$ opleidingen. De positie van de Nederlandse $\mathrm{MBO}-4$ opleidingen ten opzichte van andere beroepsopleidingen in Nederland en ten opzichte van vergelijkbare beroepsopleidingen in het buitenland is niet helemaal duidelijk. Als we kijken naar de cumulatieve opleidingsduur, dan is de $\mathrm{MBO}_{-4}$ opleiding, met nominaal 8 jaar na basisonderwijs, zelfs langer dan de korte opleidingen in het $\mathrm{HBO}$ (de tweejarige Associate Degree opleidingen), met nominaal 7 jaar na basisonderwijs. Het niveau van deze Associate Degree opleidingen ligt formeel tussen $\mathrm{MBO}_{-4}$ en $\mathrm{HBO}$ Bachelor en wordt internationaal gerekend tot het hoger onderwijs (ISCDED $5 \mathrm{~B}$ ), terwijl de $\mathrm{MBO}_{4} 4$ opleidingen tot het secundair beroepsonderwijs worden gerekend (ISCED 3). In vergelijking met andere landen heeft Nederland nog weinig van deze Associate Degree opleidingen. Ook wanneer we kijken naar vergelijkbare secundaire beroepsopleidingen in het buitenland, dan lijkt de Nederlandse $\mathrm{MBO}_{-4}$ opleiding relatief lang te zijn. Maar dat zegt op zichzelf nog niet zoveel. Voor de bepaling van de positie en plaats van de $\mathrm{MBO}-4$ opleidingen gaat het niet alleen om de cumulatieve opleidingsduur, maar ook om het bereikte niveau van competenties. De vraag is dan of het niveau van competenties van $\mathrm{MBO}-4$ opleidingen vergelijkbaar is met het niveau van competenties bij korte opleidingen in het hoger onderwijs.

Op de achtergrond speelt de vraag of de Nederlandse $\mathrm{MBO}-4$ opleiding nu tot het secundair beroepsonderwijs moet worden gerekend (ISCED 3 of 4 ) of tot het tertiair onderwijs (ISCED 5 b)? Een goed antwoord op deze vraag is van belang in het kader van de gewenste verhoging van de doorstroom naar het hoger onderwijs. Dit kan onder meer door vergroting van de toegankelijkheid van het hoger onderwijs. Verhoging van het opleidingsniveau van de beroepsbevolking past in het streven van de Europese Unie om van Europa de meest concurrerende en dynamische kenniseconomie te maken.

Om deze vraag te kunnen beantwoorden voert het ECBO onderzoek uit waarbij naast internationale systeemvergelijkingen ook een vergelijking wordt gemaakt van curricula. Daarnaast is het zinvol om een vergelijking te maken van de arbeidsmarktpo- 
sitie van de $\mathrm{MBO}_{-4}$ opleidingen en andere opleidingen. Het ECBO heeft het ROA verzocht dit laatste deel van het onderzoek uit te voeren.

\subsection{Opzet van het onderzoek}

In de theorie van het menselijk kapitaal wordt verondersteld dat elk jaar additionele scholing de productiviteit van iemand met een bepaald percentage doet toenemen. Deze hogere productiviteit wordt op de arbeidsmarkt verzilverd door een hogere beloning, een hogere kans op werk, een grotere baanzekerheid et cetera. Om die reden zien we in het arbeidsmarktonderzoek vaak een lineair verband tussen aantal jaren scholing en allerlei arbeidsmarktuitkomsten. Van der Velden et al. (2002) hebben deze algemene relatie tussen aantal jaren scholing en arbeidsmarktuitkomsten gebruikt om een model te ontwikkelen om na te gaan of een bepaald type opleiding, gegeven het aantal jaren scholing, relatief boven of onder de verwachting scoort. Wij zullen ditzelfde model gebruiken om na te gaan of de positie van $\mathrm{MBO}-4$ opleidingen dichter bij het niveau van hbo bachelor ligt dan op grond van het aantal jaren scholing verwacht zou kunnen worden. En omgekeerd: of er een groter verschil is in arbeidsmarktpositie tussen $\mathrm{MBO}_{-4}$ en $\mathrm{MBO}-3$ opleidingen dan op grond van het ene jaar verschil in scholing verwacht kan worden. Wanneer er sprake is van dit soort afwijkingen van de verwachting, zou dat een reden kunnen zijn om de cesuur tussen secundair en tertiair onderwijs niet bij $\mathrm{MBO}_{-4}$, maar bij $\mathrm{MBO}_{-3}$ opleidingen te leggen. Overigens moeten we ons daarbij realiseren dat een dergelijke uitkomst niet alleen op basis van een analyse van arbeidsmarktuitkomsten getrokken kan worden. Net zo belangrijk is immers welke positie de $\mathrm{MBO}_{4} 4$ opleidingen in internationaal opzicht innemen.

Het onderhavige onderzoek is uitsluitend gericht op de Nederlandse situatie waarbij de $\mathrm{MBO}_{-4}$ opleidingen vergeleken worden met de naast lager en hoger gelegen beroepsopleidingen. Voor het onderzoek is gebruik gemaakt van de schoolverlatersdata (schoolverlatersinformatiesysteem: SIS) van het ROA, evenals van de cohortonderzoeken van het CBS. Het grote voordeel van de SIS data is dat er voor alle opleidingstypen vergelijkbare informatie verzameld is over de arbeidsmarktsituatie anderhalf jaar na het verlaten van de opleiding. Deze informatie betreft onder meer zoekduur tot de eerste baan na het verlaten van de opleiding, werkloosheid op het moment van de enquête, beloning en baanzekerheid in de huidige functie, aansluiting tussen opleiding en huidige functie naar niveau en richting, parttime werk, carrièremogelijkheden en tevredenheid met de huidige functie. Deze informatie is voor verschillende jaargangen schoolverlaters beschikbaar.

Naast deze analyses op basis van SIS zijn we ook geïnteresseerd in het niveau van vaardigheden van degenen die een opleiding in het $\mathrm{MBO}$ of het $\mathrm{HBO}$ verlaten. Helaas bestaan er geen databronnen die deze kennis en vaardigheden op het moment van verlaten van de opleiding meten. Daarom maken we gebruik van een proxy van deze kennis en vaardigheden. Deze proxy wordt ontleend aan de cohortonderzoeken van 
het CBS: de VOCL-data. In deze longitudinale onderzoeken wordt telkens een groep van ongeveer 20.000 leerlingen, die op dat moment 12 jaar oud zijn, gevolgd tijdens hun loopbaan in het onderwijs. In dit onderzoek hebben we gebruik gemaakt van VOCL-99. Het VOCL-99 cohort was I2 jaar in 1999. In 2003 konden zij via het $\mathrm{VMBO}$ op I6-jarige leeftijd naar het $\mathrm{MBO}$, om I tot 4 jaar later, afhankelijk van het $\mathrm{MBO}$-niveau uit te stromen met een BOL-diploma. Bij de start, dat wil zeggen op I2-jarige leeftijd, wordt bij alle leerlingen een aantal testen afgenomen: voor taal, rekenen en informatieverwerking. Daarnaast wordt een IQ-test afgenomen. We zullen deze testscores als proxy gebruiken voor de kennis en vaardigheden waarmee leerlingen de opleiding $\mathrm{MBO}$ of $\mathrm{HBO}$ verlaten. In hoofdstuk 3 wordt nader uitgewerkt waarom deze scores een goede proxy zijn en waarom ze voor ons doel eerder een onderschatting geven van de afstand tussen $\mathrm{MBO}_{-4}$ opleidingen en $\mathrm{HBO}$-bachelor dan een overschatting.

\subsection{Leeswijzer}

Hoofdstuk 2 gaat in op theorieën die handvaten kunnen aanreiken voor de interpretatie van de onderzoeksresultaten met betrekking tot de arbeidsmarktopbrengsten van MBO-4 opleidingen ten opzichte van de naast lager en hoger gelegen beroepsopleidingen.

In hoofdstuk 3 wordt het analyse model besproken.

In hoofdstuk 4 worden de kennis en vaardigheden voorafgaand aan de opleiding en de opbrengsten op de arbeidsmarkt I,5 jaar na afstuderen voor schoolverlaters van $\mathrm{MBO}-4$ opleidingen in vergelijking met de naast lager en hoger gelegen beroepsopleidingen beschreven en nader geanalyseerd. Achtereenvolgens wordt ingegaan op de kennis en vaardigheden (paragraaf 4.I), de kans op werk (paragraaf 4.2), de aansluiting tussen opleiding en werk naar niveau en richting (paragraaf 4.3), beloning en carrièremogelijkheden (paragraaf 4.4), overige arbeidsvoorwaarden (paragraaf 4.5) en oordelen over de opleiding (paragraaf 4.63). Tot slot van hoofdstuk 4 worden de belangrijkste bevindingen in paragraaf 4.7 kort samengevat.

Hoofdstuk 5 bevat de conclusies. 



\section{Theoretische achtergrond}

In dit hoofdstuk wordt bekeken in hoeverre arbeidsmarkttheorieën aanknopingspunten bieden voor de vorm van de relatie tussen het aantal jaren onderwijs enerzijds en arbeidsmarktopbrengsten van onderwijs anderzijds.

\section{Human capital theorie}

De human capital theorie vindt zijn oorsprong in het werk van Becker (1964). Deze theorie legt een directe, positieve relatie tussen opleidingsniveau (ofwel aantal jaren onderwijs) en productiviteit (en daarmee beloning). Hoe hoger het opleidingsniveau, hoe hoger de beloning. Sterker nog, het rendement (in termen van procentuele verhoging van de beloning) van een extra jaar onderwijs wordt constant verondersteld. Met andere woorden, het volgen van een extra jaar onderwijs door een VMBO'er levert hetzelfde rendement op als het volgen van een extra jaar onderwijs door een academicus (beiden gaan bijvoorbeeld $5 \%$ meer verdienen). Bij dit alles speelt de context (de baan) volgens de human capital theorie geen rol. Op basis van de human capital theorie zouden we dus verwachten dat er een lineair verband bestaat tussen aantal jaren onderwijs en verdiensten. De afstand tussen BOL niveau 3 en BOL niveau 4 zou dus in salaris ongeveer een jaar moeten zijn. De afstand tussen BOL niveau 4 en $\mathrm{HBO}$ daarentegen zou veel groter moeten zijn en overeenkomen met vier jaar extra onderwijs. De human capital theorie verwacht geen directe relatie tussen aantal jaren onderwijs en andere arbeidsmarktuitkomsten, zoals zoekduur tot de eerste baan, kans op werk en andere baankenmerken. Zo wordt er niet verwacht dat lager opgeleiden vaker werkloos zijn omdat zij voor een lager loon beschikbaar zijn op de arbeidsmarkt voor lagere banen en dus niet direct concurreren met hoger opgeleiden die voor een hoger loon werken.

\section{Screening theorie}

In tegenstelling tot de human capital theorie gaat de screening theorie er van uit dat de in de baan vereiste kennis en vaardigheden de productiviteit en daarmee de beloning bepalen. De vraag is dan hoe mensen in die banen terecht komen. Hier speelt hun opleidingsachtergrond een centrale rol: de opleiding vormt het criterium op basis waarvan de werkgever de mate van geschiktheid van een potentiële werknemer bepaalt. De opleiding fungeert hierbij als het ware als screening device. Nauw verwant aan de screening theorie is de theorie van de arbeidsrij, waarbij een wachtrij 
als metafoor voor dit selectieproces wordt gebruikt (Thurow, 1975). Hierbij plaatst de werkgever de sollicitanten in een wachtrij volgens het principe: hoe geschikter (hoger opgeleid) de sollicitant, hoe beter zijn/haar plaats in de rij.

De geschiktheid van de sollicitant bepaalt de mate waarin aanvullende training nodig is en de snelheid waarmee een nieuwe werknemer zelfstandig aan de slag kan. Hierbij wordt de opleiding als graadmeter voor deze aanpassingskosten beschouwd: hoe hoger het opleidingsniveau, hoe lager de aanpassingskosten en dus hoe beter de plaats in de wachtrij. Op basis van deze theorie verwachten we dus niet alleen een lineair effect van jaren onderwijs op loon, maar ook op zoekduur, kans op werk en andere baankenmerken, zoals de kans op een baan op niveau en de kans op een vaste aanstelling.

\section{Job matching theorie}

Daar waar de human capital theorie de nadruk legt op persoonskenmerken (aantal jaren onderwijs) en de screening theorie op baankenmerken (vereiste kennis en vaardigheden), legt de job matching theorie de nadruk op de interactie tussen persoonskenmerken en baankenmerken (Hartog, I992; Hartog, 2000; Jovanovic, I979; Sattinger, 1993). Hoe beter de match tussen de verworven kennis en vaardigheden van een persoon en de in de baan vereiste kennis en vaardigheden, hoe beter iemand functioneert en daarmee hoe hoger de beloning. De allocatie van mensen over banen is hierbij dus belangrijk. Deze allocatie is optimaal als iemand een comparatief voordeel heeft in de baan (Sattinger, 1975). Van belang is dat deze theorie voorspelt dat degenen die onder hun niveau terecht komen minder verdienen dan degenen die op hun eigen niveau werkzaam zijn. Volgens deze theorie wordt er dus alleen een lineair effect van jaren onderwijs op loon verwacht indien de gediplomeerden een goede verticale match hebben; oftewel minimaal op hun eigen niveau werkzaam zijn.

\section{Segmenteringstheorieën}

Deze zijn gebaseerd op de notie dat er niet sprake is van één arbeidsmarkt, maar van arbeidsmarktsegmenten met ieder hun eigen allocatiemechanismen. Interessant in dit kader is de theorie van Lutz en Sengenberger (1974) waarin een relatie wordt gelegd tussen de allocatiemechanismen in de verschillende segmenten van de arbeidsmarkt en de daarin vereiste kwalificaties. Volgens Lutz en Sengenberger is er sprake van drie arbeidsmarktsegmenten, namelijk de bedrijfsspecifieke deelmarkt, de beroepsspecifieke of vakdeelmarkt en de niet-specifieke deelmarkt (“Jedermanns Qualifikation").

- In bedrijfsspecifieke deelmarkten spelen bedrijfsspecifieke vaardigheden een belangrijke rol. Vanuit de optiek van de werkgever heeft het initieel onderwijs vooral als taak cognitieve vaardigheden bij te brengen, die de werknemer in staat moeten stellen zich de noodzakelijke bedrijfsspecifieke vaardigheden eigen te maken. Een opleiding op minstens middelbaar niveau is daarom essentieel om toegang te krijgen tot bedrijfsspecifieke deelmarkten. 
- In vakdeelmarkten draait het vooral om beroepsspecifieke vaardigheden. Vanuit de optiek van de vakdeelmarkt heeft het initieel onderwijs vooral als taak beroepsspecifieke vaardigheden bij te brengen.

- In de niet-specifieke deelmarkt zijn geen of uitsluitend zeer basale kennis en vaardigheden vereist, dat door laag opgeleiden wordt verricht. De arbeidsvoorwaarden zijn over het algemeen aanzienlijk slechter dan in de bedrijfsspecifieke en vakdeelmarkten.

Het onderscheid tussen bedrijfsspecifieke deelmarkten, vakdeelmarkten en niet-specifieke deelmarkten onderstreept het belang van een goed en voor iedereen toegankelijk (middelbaar) beroepsonderwijs (van der Velden et al, 2002). Immers, onderwijs op middelbaar of hoger niveau is essentieel om schoolverlaters de algemene cognitieve vaardigheden bij te brengen die toegang verschaffen tot bedrijfsspecifieke deelmarkten of de beroepsspecifieke kennis en vaardigheden die de toegang tot vakdeelmarkten mogelijk maken.

Gediplomeerden van het $\mathrm{MBO}$ zullen in de regel aangewezen zijn op vakdeelmarkten, maar hiervoor is wel een voldoende basis aan beroepsspecifieke kennis en vaardigheden noodzakelijk. Zonder startkwalificatie (dat wil zeggen zonder een diploma op minimaal BOL niveau 2) rest vaak slechts een plek in de niet-specifieke deelmarkt, met slechte arbeidsmarktuitkomsten als lage lonen en slechte werkzekerheid als gevolg. Volgens deze theorie verwachten we dus grote verschillen tussen gediplomeerden van BOL niveau I en de overige gediplomeerden. 



\section{Modellering}

Om zicht te krijgen op de performance tijdens de arbeidsmarktintrede van schoolverlaters van $\mathrm{MBO}_{-4}$ opleidingen in vergelijking met de naast lager en hoger gelegen beroepsopleidingen is op basis van schoolverlatersdata gekeken naar een aantal aspecten van de arbeidsmarktintrede, zoals zoekduur tot de eerste baan of de beloning. Hierbij veronderstellen we dat schoolverlaters van een hoger opleidingsniveau over het algemeen succesvoller zijn op de arbeidsmarkt dan schoolverlaters van een lager opleidingsniveau. Bij een continue relatie tussen opleidingsniveau (lees opleidingsduur) en opbrengsten op de arbeidsmarkt verbetert de arbeidsmarktpositie van schoolverlaters met een vast percentage per elk jaar additioneel onderwijs. Bij een discontinue relatie is sprake van een buitenproportionele verbetering in de arbeidsmarktpositie vanaf een bepaald opleidingsniveau. Het bestaan van een dergelijke 'knik' in de relatie geeft aan bij welk opleidingsniveau een relatief sterke winst te behalen is ten opzichte van het voorgaande niveau (van der Velden et al, 2002). Dit kan eventueel als onderbouwing worden gebruikt voor het beleid om $\mathrm{MBO}-4$ opleidingen eerder tot de aangrenzende lager gelegen beroepsopleidingen of tot de aangrenzende hoger gelegen beroepsopleidingen te rekenen. We kunnen dat als volgt illustreren.

\section{Figuur 3.1a}

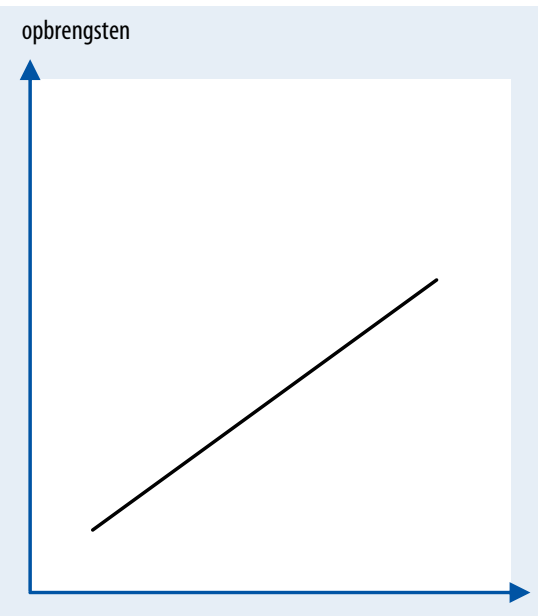

Aantal jaren scholing
Figuur 3.1b

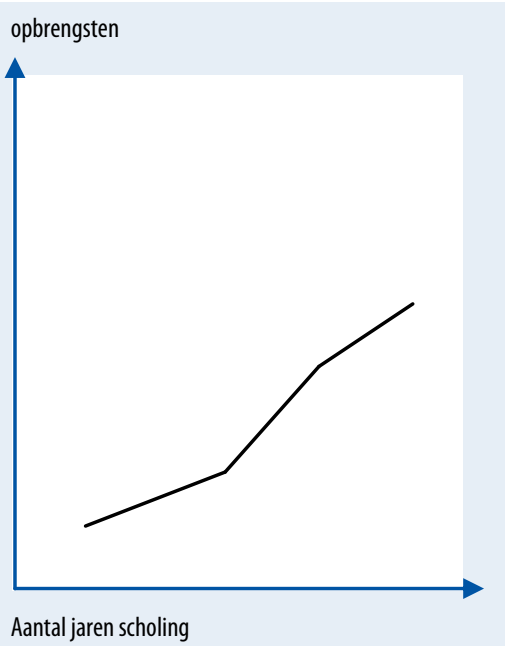


In de linkerfiguur zien we een lineair verband tussen het aantal jaren scholing en de opbrengsten op de arbeidsmarkt. In de rechterfiguur zien we duidelijk twee knikken. Van de eerste naar de tweede knik is sprake van een sterke relatieve stijging van de opbrengsten. Stel nu dat de eerste knik bij MBO-3 zou liggen en de tweede knik bij $\mathrm{MBO}_{-4}$, dan betekent dit dat de 'afstand' tussen $\mathrm{MBO}_{-3}$ en $\mathrm{MBO}_{4}$ in termen van opbrengsten groter is dan je zou vermoeden op grond van het ene jaar verschil in scholing. In dat geval zou dat betekenen dat de scheiding tussen secundair en tertiair onderwijs wellicht tussen $\mathrm{MBO}-3$ en $\mathrm{MBO}_{-4}$ getrokken moet worden.

We gaan deze methodiek toepassen om te kijken wat de positie is van MBO-4 opleidingen in vergelijking met de aangrenzende lager en hoger gelegen beroepsopleidingen. We doen dit aan de hand van een achttal arbeidsmarktindicatoren. De informatie is ontleend aan het SchoolverlatersInformatieSysteem (SIS) en betreft de zoekduur tot de eerste baan, de kans op betaald werk, de kans op een voltijdbaan, de kans op een vaste baan, de kans op een baan op eigen opleidingsniveau, de kans op een baan in de eigen opleidingsrichting, het bruto uurloon en de tevredenheid met de baan. Om ook zicht te krijgen op de waarde van de betreffende opleidingen op lange termijn is bovendien gekeken naar de mate waarin de opleiding schoolverlaters voldoende kennis en vaardigheden bijbracht om te starten op de arbeidsmarkt en om hun kennis en vaardigheden verder te blijven ontwikkelen. Daarnaast kijken we naar de carrièremogelijkheden die schoolverlaters zien in hun huidige functie. Deze indicatoren geven een goed beeld wat de opleiding oplevert voor schoolverlaters die de arbeidsmarkt betreden.

Zoals in het vorige hoofdstuk al is aangegeven zijn er geen eensluidende verwachtingen vanuit de theorieën over de relatie tussen aantal jaren scholing en opbrengsten. Alleen voor uurloon wordt vanuit elke theorie een duidelijk lineair verband voorspeld. Dat betekent ook dat we uurloon als de meest 'harde' indicator zullen beschouwen.

Om de invloed van periode-effecten zo klein mogelijk te houden, zijn alleen schoolverlatersdata vanaf meting 2005 gebruikt en om de populatie zo homogeen mogelijk te houden zijn voor wat betreft het $\mathrm{HBO}$ alleen data van schoolverlaters van voltijd HBO opleidingen gebruikt. Verder is de analyse gericht op schoolverlaters van de BOL die niet ouder zijn dan 25 jaar en op schoolverlaters van het $\mathrm{HBO}$ die niet ouder zijn dan 30 jaar. Tot slot zijn schoolverlaters van het duale MBO (BBL) in de analyse niet meegenomen omdat in de BBL de opleiding parttime vanuit een baan wordt gevolgd en schoolverlaters van de BBL gemiddeld zo'n 8 jaar ouder zijn dan schoolverlaters van de BOL. In de analyse maken we een bovendien een onderscheid tussen alle $\mathrm{HBO}$-ers enerziijds en degenen die voorafgaand aan de $\mathrm{HBO}$-opleiding een $\mathrm{MBO}$-opleiding hebben afgerond anderzijds. In het laatste geval kan een nog zuiverder vergelijking plaatsvinden met de schoolverlaters ven BOL niveau 4.

Naast de effecten van onderwijs op arbeidsmarktuitkomsten is ook gekeken naar de relatie met kennis en vaardigheden. Omdat er geen meting is van kennis en vaardig- 
heden op het moment dat men de opleiding verlaten heeft, hebben we een proxy gebruikt, namelijk de kennis en vaardigheden die deze leerlingen hadden op I2-jarige leeftijd. Hiervoor is gebruik gemaakt van de VOCL-99 data van het CBS. Het VOCL-99 cohort was I2 jaar in 1999. In 2003 konden zij via het VMBO op I6-jarige leeftijd naar het $\mathrm{MBO}$, om I tot 4 jaar later, afhankelijk van het MBO-niveau uit te stromen met een BOL-diploma. Omdat uitsluitend hele snelle leerlingen al een opleiding in het $\mathrm{HBO}$ kunnen hebben afgerond is de selectie hier wat anders geweest. Enerzijds zijn leerlingen geselecteerd die een diploma hebben behaald in het MBO (BOL) en daarna het onderwijs hebben verlaten. Deze leerlingen zijn ingedeeld naar hoogst behaalde opleidingsniveau (BOL I, 2, 3 of 4 ). Daarnaast zijn de leerlingen geselecteerd die gestart zijn met een opleiding in het $\mathrm{HBO}$ en die hetzij gediplomeerd verlaten hebben, hetzij daar nog op zitten. Van al deze leerlingen is de volgende informatie bekeken: de score op de CITO entreetoets voor de onderdelen (I) taal, (2) rekenen en (3) informatieverwerking en (4) totaal. Bovendien gebruiken we ook de scores van de IQ-test voor de onderdelen (I) verbaal (2) symbolisch (ruimtelijk) en (3) totaal.

Wat betekent het nu voor onze analyses dat we niet de kennis en vaardigheden meten op het moment van verlaten van de opleiding, maar in plaats daarvan een proxy nemen op basis van de kennis en vaardigheden op I2-jarige leeftijd? We kunnen dat het beste illustreren aan de hand van figuur 3.2.

\section{Figuur 3.2}

Niveau vaardigheden bij verlaten opleiding en op 12-jarige leeftijd

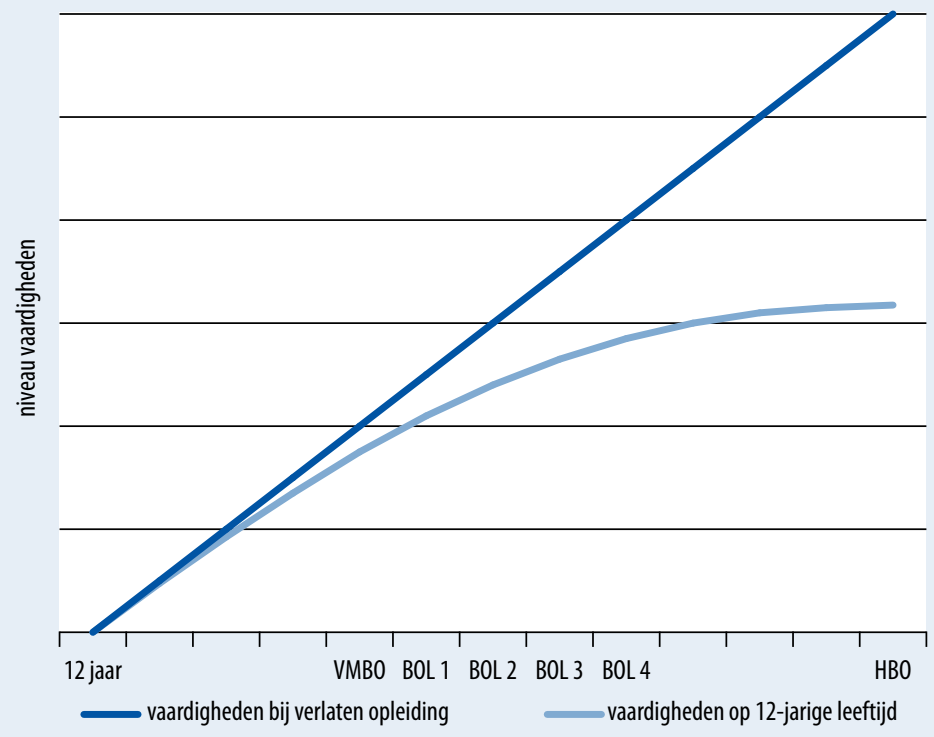


De rechte lijn geeft het verband weer tussen aantal jaren scholing en het bereikte niveau van kennis en vaardigheden. In lijn met de theorie van het menselijk kapitaal veronderstellen we dat deze relatie lineair is: elk jaar additionele scholing geeft een bepaald percentage extra kennis en vaardigheden. De kromme lijn geeft het verband weer tussen aantal jaren scholing en het niveau van kennis en vaardigheden op twaalfjarige leeftijd. In het begin van de loopbaan komen kennis en vaardigheden op twaalfjarige leeftijd en bereikt niveau van kennis en vaardigheden per definitie sterk overeen. En hoewel kennis en vaardigheden op twaalfjarige leeftijd een zeer sterke voorspeller is van het uiteindelijk bereikte niveau van onderwijs, ontstaat er meer 'afstand' naarmate men meer jaren scholing gevolgd heeft. ${ }^{I}$ Een belangrijke reden hiervoor is dat twee leerlingen met gelijke capaciteiten op twaalfjarige leeftijd, toch een verschillende schoolloopbaan kunnen hebben. Als gevolg hiervan zullen ze ook verschillen in het bereikte niveau van kennis en vaardigheden. Hoe meer jaren scholing men heeft gevolgd, hoe meer afstand er is tussen de kennis en vaardigheden op twaalfjarige leeftijd en het uiteindelijke niveau van kennis en vaardigheden. Voor onze analyse betekent dit dat het verschil in CITO-score tussen BOL-4 en $\mathrm{HBO}$ bachelor kleiner is dan het verschil tussen $\mathrm{VMBO}$ en $\mathrm{BOL}-4$, ofschoon in termen van jaren scholing in beide gevallen sprake is van vier jaar verschil. Met andere woorden, het gebruik van een proxy leidt tot een onderschatting van het uiteindelijk bereikte niveau van kennis en vaardigheden en geeft daarmee een conservatieve schatting van het aantal jaren verschil tussen BOL-4 en $\mathrm{HBO}$ bachelor.

Voor iedere indicator is de score van de opleidingen op de betreffende indicator bepaald, rekening houdend met individuele kenmerken van de schoolverlaters (geslacht, leeftijd, etniciteit, gevolgde opleidingssector en het jaar van het behalen van het diploma; bij de VOCL analyses uitsluitend geslacht en etniciteit). Hierdoor kan het effect van het gevolgde opleidingsniveau zo zuiver mogelijk worden geschat. Het is immers mogelijk dat eventuele verschillen tussen de opleidingen worden veroorzaakt door bijvoorbeeld leeftijdsverschillen of verschillen tussen opleidingen in het jaar van uitstroom. De figuren geven de resultaten weer voor BOL niveau i t $/ \mathrm{m}$ BOL niveau 4 en het HBO. De cijfers geven de parameterschattingen weer voor de betreffende opleidingsniveaus, waarbij BOL-4 als referentiecategorie dient. Dat wil zeggen dat het effect van BOL-I, BOL-2, BOL-3 en HBO is vergeleken met het effect van BOL-4. De betreffende cijfers geven derhalve de afwijking ten opzichte van de BOL niveau 4 weer, en kunnen worden geïnterpreteerd als het volgen van het desbetreffende aantal jaren beroepsonderwijs. HBO wordt als vier jaar extra ten opzichte van BOL niveau 4 weergegeven, omdat gediplomeerden van BOL-4 die doorstromen naar het $\mathrm{HBO}$ hier normaal gesproken (net als HAVO-gediplomeerden) vier jaar over dan. Verkorte trajecten in drie jaar kunnen wel voorkomen, maar vier jaar is de norm.

I. Wanneer de kennis en vaardigheden op twaalfjarige leeftijd een perfecte voorspelling zou zijn geweest van het bereikte eindniveau, dan zou er een lineair verband zijn geweest. Dat betekent niet dat leerlingen in het onderwijs niets meer bijleren, maar dat de mate waarin ze bijleren perfect voorspeld wordt door kennis en vaardigheden die zeis op twaalfjarige leeftijd hebben. 
In de figuren is bovendien een trendlijn weergegeven. Deze geeft voor de betreffende indicator de gemiddelde stijging per opleidingsniveau. Bij een continu model mag worden verwacht dat de vergelijking tussen de opleidingen een lineair verband oplevert, omdat een toename van één niveau ook één jaar meer onderwijs betekent. Tevens is in de figuren vermeld of de verschillen tussen opleidingsniveaus significant zijn. Op deze manier wordt aangegeven of een toename van één onderwijsniveau voor schoolverlaters significant meer oplevert op de arbeidsmarkt of significant meer kennis en vaardigheden impliceert. 



\section{De relatie tussen opleidingsniveau, vaardigheden en arbeidsmarktsucces}

\subsection{Vaardigheden}

We beginnen onze analyses met de relatie tussen opleidingsniveau en de kennis en vaardigheden. Zoals aangegeven gebruiken we hiervoor een proxy, namelijk de kennis en vaardigheden gemeten op I2-jarige leeftijd. Voor de analyses hebben we gebruik gemaakt van VOCL-99 data van het CBS. Als afhankelijke variabelen hebben we de score op de CITO entreetoets gebruikt voor de onderdelen (I) taal, (2) rekenen en (3) informatieverwerking en (4) totaal. Bovendien gebruiken we ook de scores van de IQ-test voor de onderdelen (I) verbaal (2) symbolisch (ruimtelijk) en (3) totaal. Bij de analyses op basis van de VOCL-data gaat het om het voorspellen van de score op de CITO-entreetoets en op de IQ-test aan het begin van de middelbare school op basis van het aantal jaren onderwijs dat men sindsdien heeft gevolgd.

\section{CITO entreetoets taal}

In figuur 4.I worden de resultaten van de analyse van de score op de CITO entreetoets taal weergegeven.

Uit figuur 4.I blijkt dat de verschillen in voorspelde CITO-entreetoetsscore voor taal tussen de vier niveaus van BOL en het HBO bijna lineair zijn op basis van de lengte van de opleidingen. De gediplomeerden van niveau I scoorden relatief nog iets lager dan op basis van de lengte van hun latere opleiding kan worden voorspeld. De gediplomeerden van BOL niveau 4 blijken juist iets hoger te hebben gescoord op het onderdeel taal van de CITO-entreetoets. Het verschil tussen gediplomeerden van BOL niveau 4 en $\mathrm{HBO}$ is daardoor iets minder dan de verwachte 4 jaar en ligt tussen de 3 en 4 jaar. Dit is ook in lijn met de eerder geformuleerde verwachting over een grotere afstand tussen eindniveau en niveau op twaalfjarige leeftijd voor HBO gediplomeerden. Het verschil tussen gediplomeerden van BOL niveau 4 en van BOL niveau 3 is daarentegen iets groter dan verwacht. 


\section{Figuur 4.1}

Lineaire regressieanalyse van de score op de CITO entreetoets taal (score 1-20)

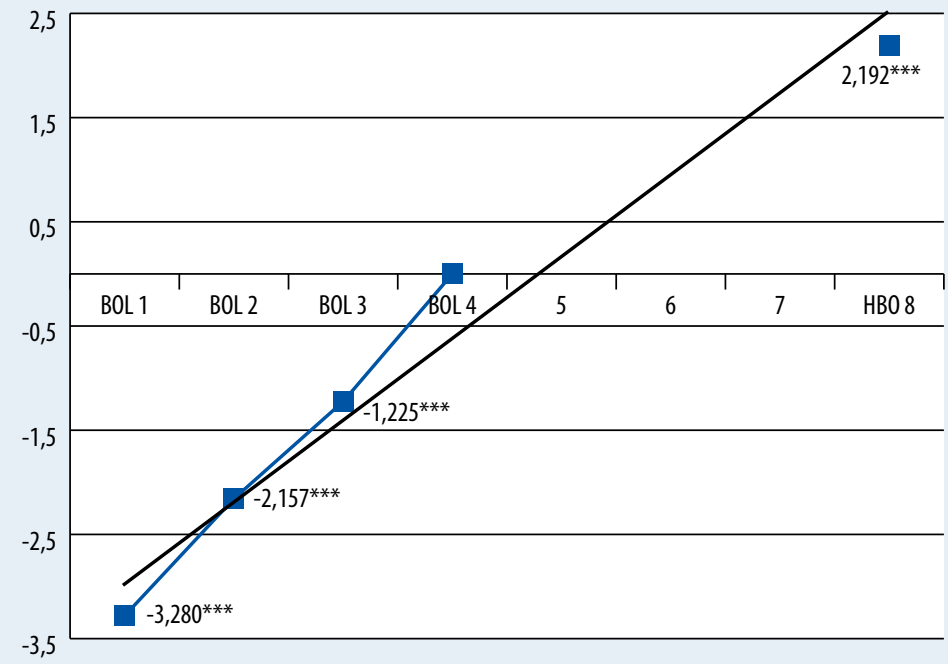

Bron: VOCL-99 / CBS

\section{CITO entreetoets rekenen}

In figuur 4.2 laten we ook voor het onderdeel rekenen van de CITO-entreetoets zien in welke mate de scores overeen komen met het niveau en de lengte van hun latere BOL- of HBO-opleiding.

Ook bij het onderdeel rekenen van de CITO-entreetoets blijkt de score een goede voorspeller van het later gevolgde onderwijs. Gediplomeerden van BOL-I, BOL-2, BOL-3 en $\mathrm{HBO}$ zitten daarbij praktisch op de trendlijn, terwijl alleen gediplomeerden BOL-4 relatief iets hoger scoorden op deze toets dan op basis van hun latere opleiding is te verwachten. Het verschil met $\mathrm{HBO}$ bedraagt tussen de 3 en 4 jaar.

\section{CITO entreetoets informatieverwerking}

In figuur 4.3 wordt ook de score op het derde onderdeel van de CITO-entreetoets voorspeld op basis van de later gevolgde beroepsopleiding. 
Figuur 4.2

Lineaire regressieanalyse van de score op de CITO entreetoets rekenen (score 1-20)

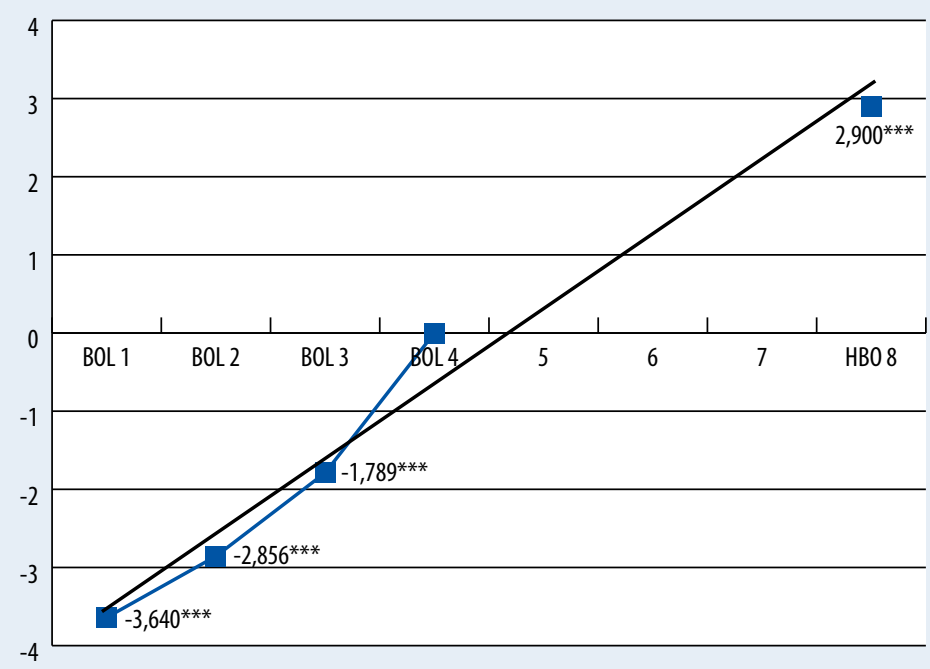

Bron: VOCL-99 / CBS

Figuur 4.3

Lineaire regressieanalyse van de score op de CITO entreetoets informatieverwerking (score 1-20)

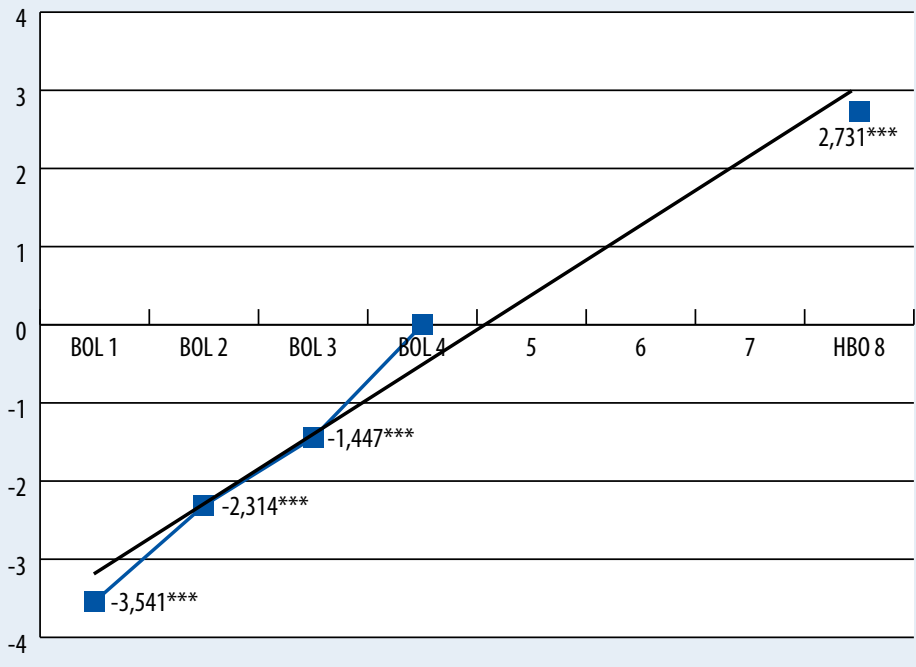

Bron: VOCL-99 / CBS 
Ook bij het onderdeel informatieverwerking is de relatie tussen latere jaren onderwijs en de score op de entreetoets nagenoeg lineair te noemen. Het beeld is hetzelfde als hiervoor. De gediplomeerden van BOL-4 scoren iets hoger dan op basis van hun jaren onderwijs verwacht zou kunnen worden, maar deze afwijking is zeer gering. Wederom zitten gediplomeerden van BOL-I, BOL-2, BOL-3 en HBO zo'n beetje op de trendlijn.

\section{CITO entreetoets totaal}

Vervolgens voorspellen we ook de totaalscore op de CITO-entreetoets op basis van het niveau van het later afgerond beroepsonderwijs. In figuur 4.4 worden de resultaten van deze analyse grafisch weergegeven.

\section{Figuur 4.4}

Lineaire regressieanalyse van de totaalscore op de CITO entreetoets (score 1-60)

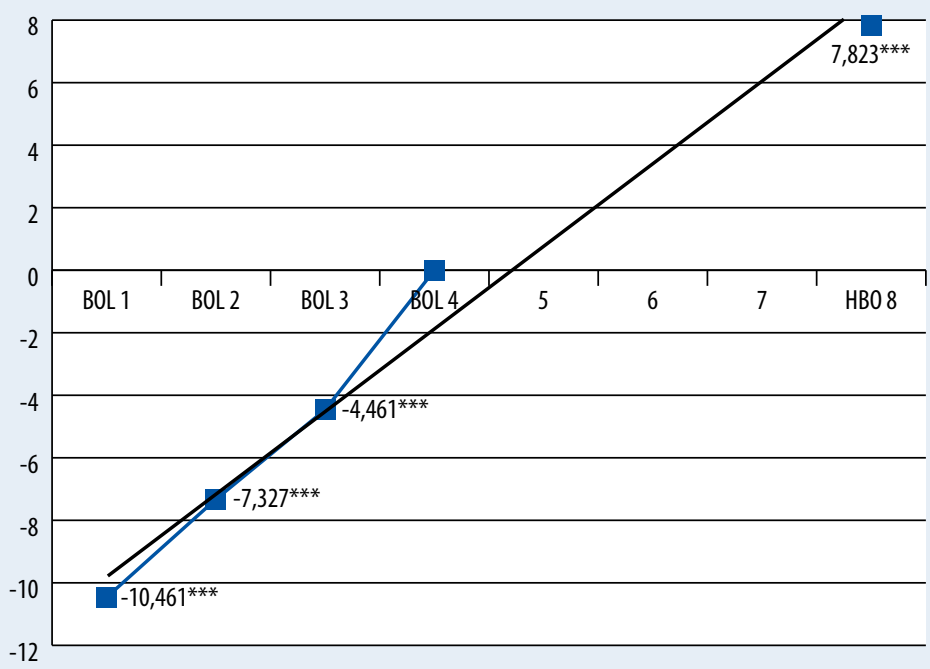

Bron: VOCL-99 / CBS

Het patroon dat al zichtbaar werd in de verschillende onderdelen van de entreetoets komt uiteraard ook in de analyse van de totaalscore naar voren. Wederom bevinden de schattingen voor BOL-I, BOL-2, BOL-3 en HBO zich bijna precies op de trendlijn. Daarnaast blijken ook hier de gediplomeerden van BOL-4 iets hoger op de CITO entreetoets te scoren dan te verwachten valt op basis van hun later gevolgde opleiding. De verschillen tussen BOL- 4 en $\mathrm{HBO}$ bedragen tussen de 3 en 4 jaar en tussen BOL-3 en BOL-4 tussen de I en 2 jaar. Al met al lijkt er een lineair verband te zijn tussen jaren onderwijs en toetsscore bij aanvang van de middelbare school en is er op grond van deze analyse geen aanleiding om BOL-4 tot het hoger onderwijs te rekenen. 


\section{IQ Verbaal}

Naast de entreetoets is er in de VOCL-data ook een IQ-test gedaan door de respondenten op I2-jarige leeftijd. Hierbij zijn er twee verschillende onderdelen getoetst: verbaal IQ en symbolisch IQ. Eerst beschrijven we de resultaten van de twee deeltesten, daarna staan we stil bij de totaalscore. In figuur 4.5 worden de resultaten van de analyse van verbaal IQ grafisch weergegeven.

\section{Figuur 4.5}

Lineaire regressieanalyse van de score op verbaal IQ

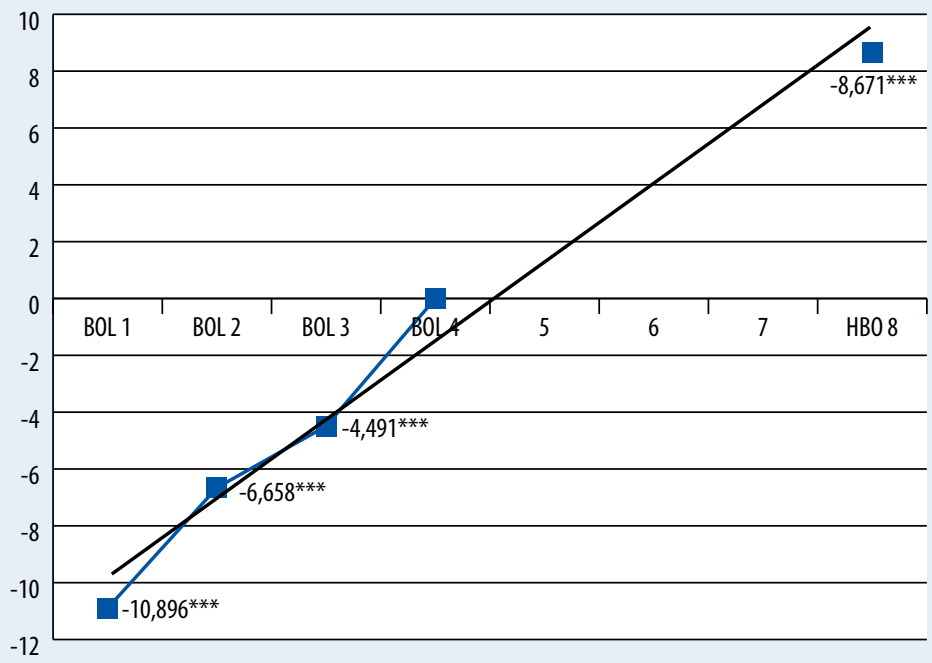

Bron: VOCL-99 / CBS

Ook de verbale IQ test blijkt zeer goed te kunnen worden voorspeld op basis van later gevolgde jaren onderwijs. Er lijkt weer sprake te zijn van een lineaire relatie tussen jaren onderwijs en verbale IQ- score. Gediplomeerden van BOL niveau 4 hebben weer een iets hogere verbale IQ-score dan op basis van de trend te verwachten is, maar voor de rest liggen de schattingen voor de overige gediplomeerden dicht bij of op de trendlijn.

\section{IQ symbolisch}

In figuur 4.6 geven we de grafische weergave van de resultaten van de analyse van symbolische IQ-score. 


\section{Figuur 4.6}

Lineaire regressieanalyse van de score op symbolisch IQ

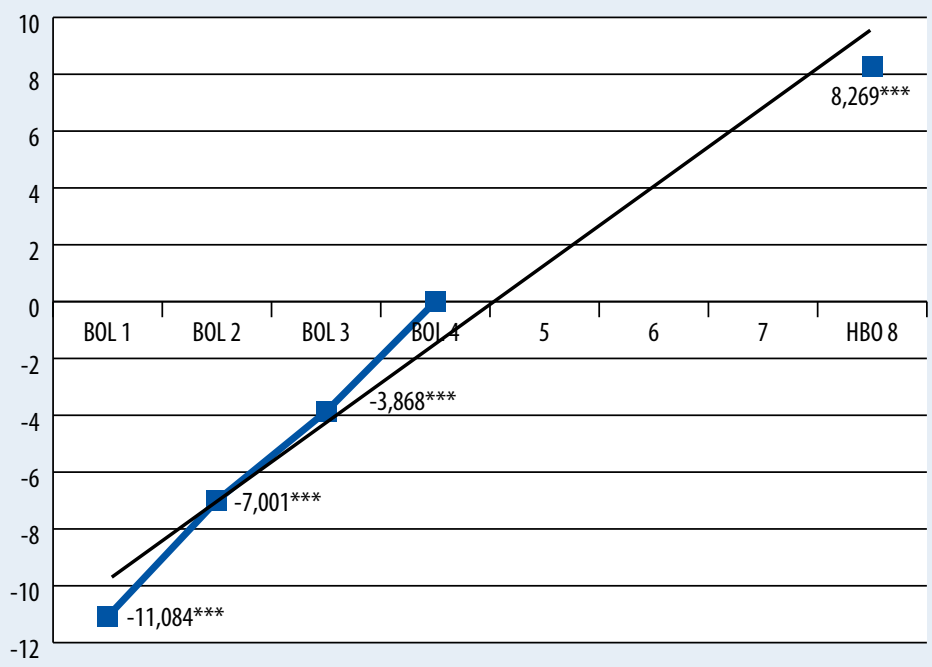

Bron: VOCL-99 / CBS

Ook bij de symbolische IQ-test (ook wel ruimtelijk IQ) zijn de verschillen in score van de gediplomeerden van de verschillende beroepsopleidingen bijna perfect lineair. Weer is de score onder de BOL-4 gediplomeerden iets hoger dan verwacht, maar de afwijking van de trend is klein.

\section{IQ Totaal}

Ten slotte geven we de resultaten van de analyse van de algemene IQ-score weer.

Het patroon uit de twee onderdelen van IQ bleek zeer identiek te zijn. Daarom vinden we voor de totaalscore bijna precies hetzelfde: een bijna perfecte lineaire relatie tussen jaren later gevolgd onderwijs en IQ-score, met alleen voor BOL-4 gediplomeerden een iets hogere score dan verwacht.

$\mathrm{Al}$ met al kunnen we op basis van de VOCL-data zeggen dat de positie van BOL niveau 4 qua vaardigheden ongeveer I jaar afstand heeft tot BOL-3 en ongeveer 3 à 4 jaar afstand van $\mathrm{HBO}$. We wijzen er nogmaals op dat de afstand tot $\mathrm{HBO}$ een conservatieve schatting is en in werkelijkheid iets meer zal bedragen. We vervolgen onze analyse met de relatie tussen opleiding en arbeidsmarktuitkomsten. 
Figuur 4.7

Lineaire regressieanalyse van de score op IQ totaal

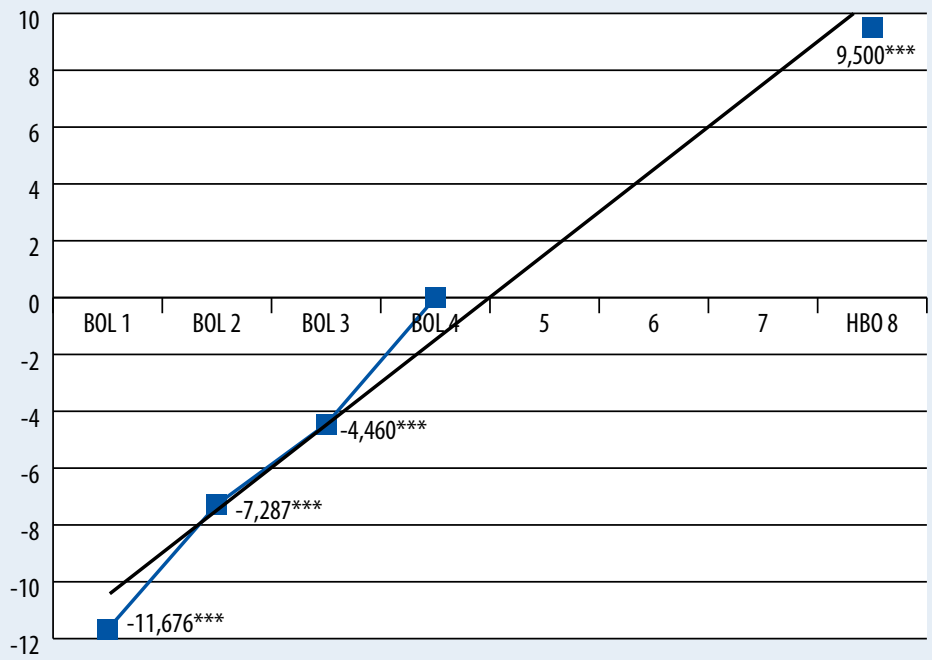

\subsection{Kans op werk}

De kans op werk tijdens de arbeidsmarktintrede wordt geschetst aan de hand van achtereenvolgens de zoekduur tot de eerste baan en de werkloosheid op het moment van de enquête.

\section{Zoekduur tot de eerste baan}

Figuur 4.8 gaat in op de zoekduur tot de eerste baan. Dit betreft het aantal maanden dat men tussen het moment van afstuderen en de eerste baan werkzoekend is geweest. De resultaten worden afzonderlijk gepresenteerd voor alle $\mathrm{HBO}$-ers enerzijds en degenen die voorafgaand aan de HBO-opleiding een $\mathrm{MBO}$-opleiding hebben afgerond anderzijds.

$\mathrm{Na}$ controle voor individuele kenmerken blijkt dat schoolverlaters van de BOL-4 opleidingen significant korter werkloos zijn geweest voordat zij de eerste baan vonden dan de andere schoolverlaters. De grootste verschillen in zoekduur tot de eerste baan manifesteren zich tussen schoolverlaters van de korte BOL opleidingen enerzijds (gemiddeld I maand of langer werkloos) en schoolverlaters van de lange opleidingen anderzijds (gemiddeld korter dan een halve maand werkloos). Wat de lengte van de zoekduur tot de eerste baan betreft, lijken schoolverlaters van BOL niveau 4 opleidingen iets meer op schoolverlaters van BOL niveau 3 opleidingen en HBO-opleidingen dan op schoolverlaters van andere beroepsopleidingen. 
Figuur $4.8 \mathrm{a}+\mathrm{b}$

Lineaire regressieanalyse van de zoekduur tot de eerste baan
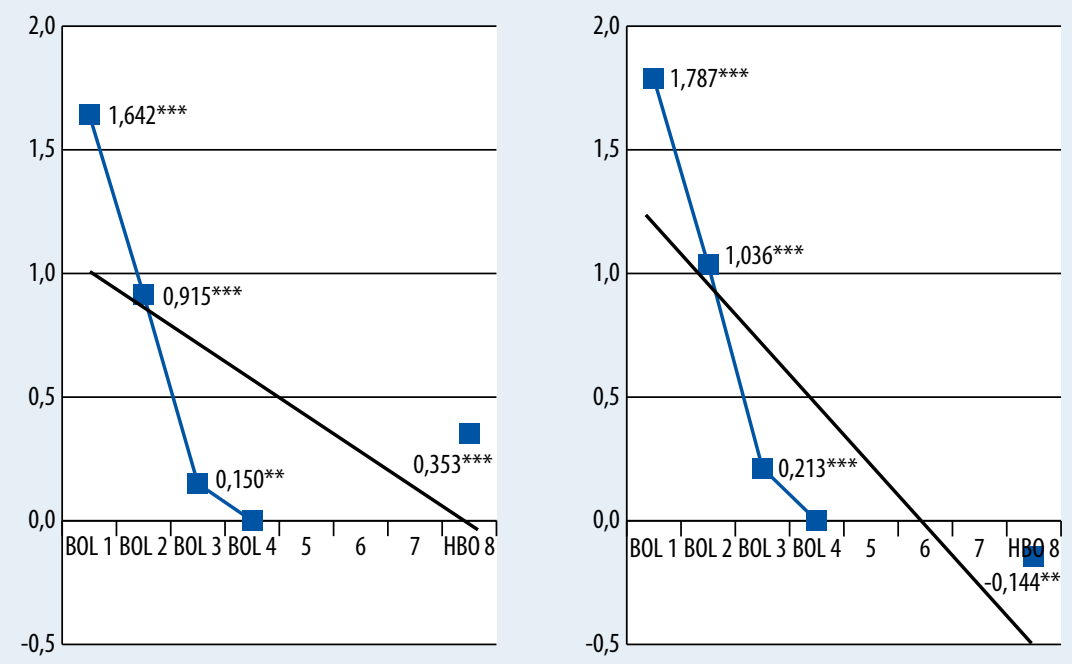

Links: met alle HBO-gediplomeerden, rechts: met alleen HBO-gediplomeerden afkomstig uit het MBO

Als we de analyse nogmaals doen met alleen $\mathrm{HBO}$-schoolverlaters die eerst een MBO-diploma hebben behaald dan zien we dat deze HBO-schoolverlaters een nog kortere zoekduur tot de eerste baan hebben dan de schoolverlaters van BOL niveau 4. Overigens vindt de grootste afname van de zoekduur tot de eerste baan plaats van BOL niveau I naar BOL niveau 2 en van BOL niveau 2 naar BOL niveau 3. Dit illustreert de waarde van een startkwalificatie op BOL niveau 2 en zelfs het extra belang van een opleiding op niveau 3 .

\section{Kans op werk op enquêtemoment}

Om de kans op werk op het moment van de enquête te bepalen, is eerst de mate waarin men op het enquêtemoment beschikbaar is voor de arbeidsmarkt (het procentuele aandeel van schoolverlaters die zich op de arbeidsmarkt aanbieden) bekeken. Vervolgens is hiervan het percentage werkzame personen bepaald. Figuur 4.9 toont de resultaten van de analyse van de kans op werk na controle voor de eerder genoemde individuele kenmerken.

Figuur 4.9 laat zien dat de kans op werk stijgt met de toename van het opleidingsniveau. Kijken we naar de mate van stijging, dan zien we dat de toename van de kans op werk het grootst is tussen BOL-2 en BOL-3 opleidingen. Als we alleen de HBO-schoolverlaters afkomstig van het $\mathrm{MBO}$ in beschouwing nemen dan wordt het verschil met BOL-4 groter: 0,85I. Dit komt overeen met een verschil van iets minder dan drie jaar. 
Figuur $4.9 a+b$

Logistische regressieanalyse van de kans op werk
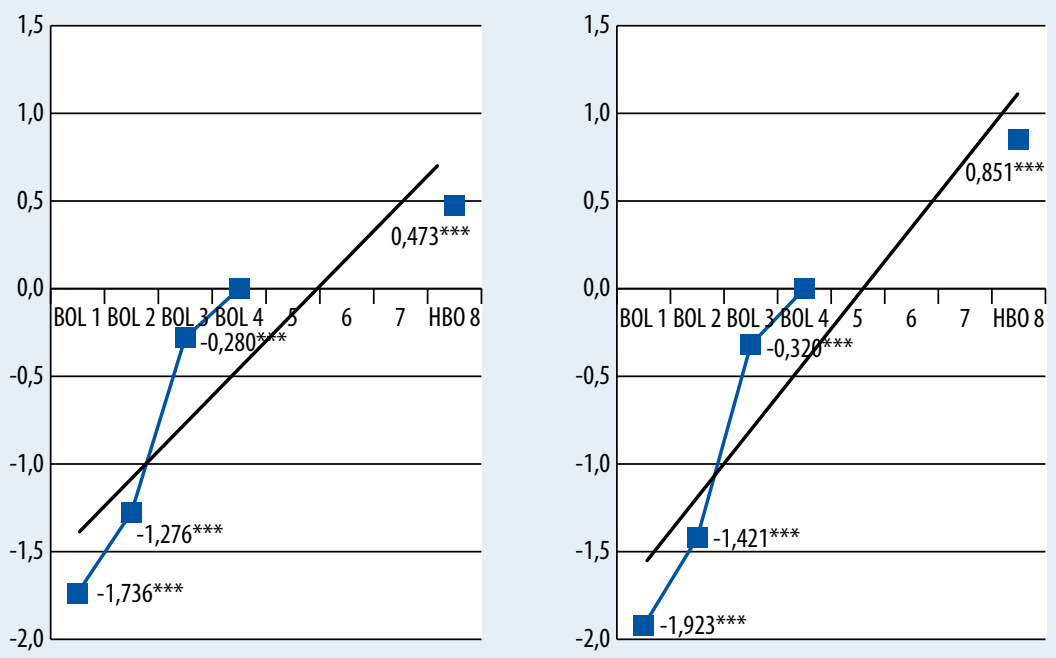

Links: met alle HBO-gediplomeerden, rechts: met alleen HBO-gediplomeerden afkomstig uit het MBO

De voorlopige conclusie is: als het gaat om de kans op werk ligt de cesuur duidelijk tussen de korte opleidingen in het $\mathrm{MBO}$ en de lange opleidingen in het $\mathrm{MBO}$. Het suggereert dat voor de kans op werk een startkwalificatie zelfs niet voldoende is, maar dat minimaal een opleiding op BOL niveau 3 gewenst is.

\subsection{Aansluiting tussen opleiding en werk}

In eerste instantie staat of valt een succesvolle intrede op de arbeidsmarkt met het al dan niet vinden van een (vaste) baan. De feitelijke werkzaamheden, verantwoordelijkheden en de inhoud van de functie bepalen in hoeverre iemand de mogelijkheid heeft om zijn of haar kennis en vaardigheden te benutten. Daarnaast bepalen de inhoud en het niveau van het werk mede de financiële vergoeding die hier tegenover staat. Dus niet alleen de kans op werk en werkzekerheid maar ook de kwaliteit van het werk bepalen in hoeverre de overgang van onderwijs naar arbeidsmarkt succesvol genoemd kan worden. Beginnende deelnemers op de arbeidsmarkt zullen vaak in startfuncties terecht komen. Ook voor deze startfuncties geldt dat voor individuen de kwaliteit van het werk toeneemt naarmate de gevonden baan beter aansluit op de gevolgde opleiding voor wat betreft richting en vooral niveau. Op de aansluiting tussen opleiding en werk naar niveau en richting wordt in deze paragraaf nader ingegaan. Hierbij is gekeken naar de opleidingseisen wat betreft niveau en richting die de werkgever stelt bij het vervullen van de vacature. 


\section{Vereist opleidingsniveau voor het werk}

Vanuit maatschappelijk oogpunt is het van belang dat schoolverlaters bij voorkeur functies vervullen die passen bij het niveau van hun opleiding. Dat is immers de grondslag van het bestaan van verschillende onderwijssoorten. Ook vanuit individueel oogpunt mag worden verondersteld dat het voor schoolverlaters belangrijk is een baan te vinden waar de in de opleiding opgedane competenties optimaal kunnen worden aangewend. Op basis van de screening theorie verwachten we hier een lineair effect van jaren onderwijs op de kans op werk op niveau. Op basis van de human capital theorie niet.

\section{Figuur 4.10a+b}

Logistische regressieanalyse van de kans op een baan op eigen opleidingsniveau
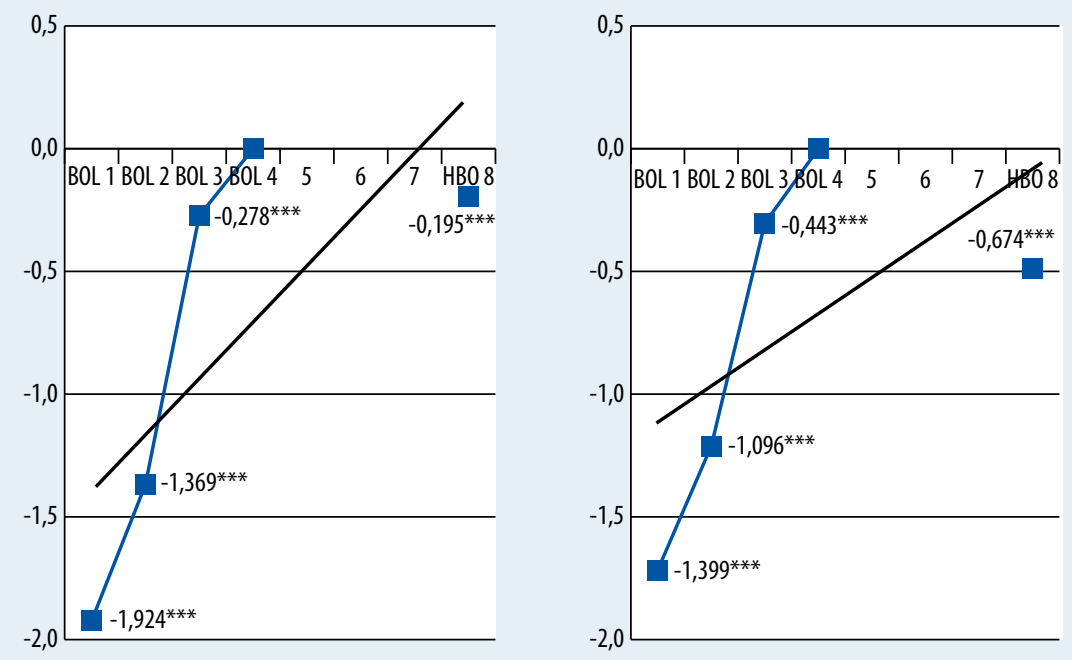

Links: met alle $\mathrm{HBO}-$ gediplomeerden, rechts: met alleen $\mathrm{HBO}$-gediplomeerden afkomstig uit het MBO

Figuur 4.IO vermeldt de resultaten met betrekking tot de kans van betaald werkende schoolverlaters op een baan op minimaal het eigen opleidingsniveau. De resultaten in figuur 4.IO laten zien dat schoolverlaters van BOL niveau 4 opleidingen de grootste kans hebben dat hun werk past bij het niveau van hun opleiding. Hun kans ligt overigens dichter bij de naast lager gelegen beroepsopleidingen (BOL niveau 3) en de $\mathrm{HBO}$ opleidingen dan bij de lagere niveaus van de BOL. Als we alleen de $\mathrm{HBO}$-ers met een $\mathrm{MBO}$-achtergrond in de analyse opnemen dan blijkt de kans op werk op niveau nog lager uit te vallen voor de $\mathrm{HBO}$-schoolverlaters ten opzichte van de schoolverlaters van BOL niveau 4 én niveau 3. 


\section{Vereiste opleidingsrichting voor het werk}

Behalve het niveau is ook de richting van de gevonden functie van belang voor de kwaliteit van het werk. In de vragenlijst is gevraagd om aan te geven wat de door de werkgever vereiste opleidingsrichting voor de functie is. De vereiste opleidingsrichting zegt iets over de mate waarin de gediplomeerde werkzaamheden verricht die binnen het beroependomein vallen waarvoor hij of zij is opgeleid. Van dit 'eigen' beroependomein is sprake wanneer voor de functie de eigen opleidingsrichting of een daaraan verwante opleidingsrichting vereist is. Werken binnen het 'eigen' beroependomein vergroot de kans dat de in het onderwijs verworven kennis en vaardigheden beter benut zullen worden. Ook vanuit maatschappelijk oogpunt is het van belang dat schoolverlaters terecht komen in beroepen waarvoor zij zijn opgeleid. Dit laatste zal zeker gelden voor de meer beroepsgerichte opleidingen in het MBO. Het voorgaande laat onverlet dat de interpretatie van de aansluiting tussen opleiding en werk naar richting minder duidelijk is dan bij de aansluiting naar niveau. Wanneer wordt verondersteld dat de aansluiting uitsluitend verloopt via vakgerelateerde competenties, zou kunnen worden beargumenteerd dat een functie waarvoor uitsluitend de eigen opleidingsrichting wordt vereist beter is dan een functie waarvoor de eigen of een verwante opleidingsrichting wordt vereist, die op zijn beurt weer beter is dan een functie waarvoor een geheel andere of geen specifieke opleidingsrichting wordt vereist. Echter, in steeds meer functies neemt het belang toe van algemene competenties die niet noodzakelijkerwijs op een bepaald vakgebied hoeven te liggen, zoals het kunnen oplossen van complexe problemen, het vermogen zich zelfstandig nieuwe kennis eigen te maken en het kunnen functioneren in een multidisciplinair team. Het valt op die manier te beargumenteren dat een functie waarvoor geen specifieke of een geheel andere opleidingsrichting wordt vereist niet per definitie slechter is dan een functie op vergelijkbaar niveau waarvoor (uitsluitend) de eigen of een daaraan verwante opleidingsrichting wordt vereist.

In figuur 4.II zijn de resultaten vermeld met betrekking tot de kans van betaald werkende schoolverlaters op een baan die qua richting aansluit bij de gevolgde opleiding.

Figuur 4.II laat zien dat voor betaald werkende schoolverlaters de kans op een baan die past bij de gevolgde opleidingsrichting toeneemt met het opleidingsniveau. De kans van BOL niveau 4 opleidingen ligt het dichtst bij de BOL niveau 3 opleidingen. Het verschil met de $\mathrm{HBO}$-opleidingen bedraagt iets minder dan drie jaar. Net als bij de kans om werk op niveau te hebben gaapt er een grote kloof tussen BOL niveaus I en 2 en BOL niveau 3 opleidingen. We zien ook in de figuur dat de BOL opleidingen van niveau 3 en 4 het iets beter doen dan te verwachten valt als er een lineaire relatie is tussen jaren onderwijs en werken binnen de eigen of verwante opleidingsrichting. De analyse waarin alleen $\mathrm{HBO}$-schoolverlaters afkomstig uit het $\mathrm{MBO}$ worden meegenomen levert een hogere schatting op voor de $\mathrm{HBO}$ schoolverlaters (met een $\mathrm{MBO}$-diploma): het verschil met BOL-4 bedraagt nu 0,77 in plaats van 0,56 . 
Figuur 4.11a+b

Logistische regressieanalyse van de kans op een baan in de eigen of verwante opleidingsrichting
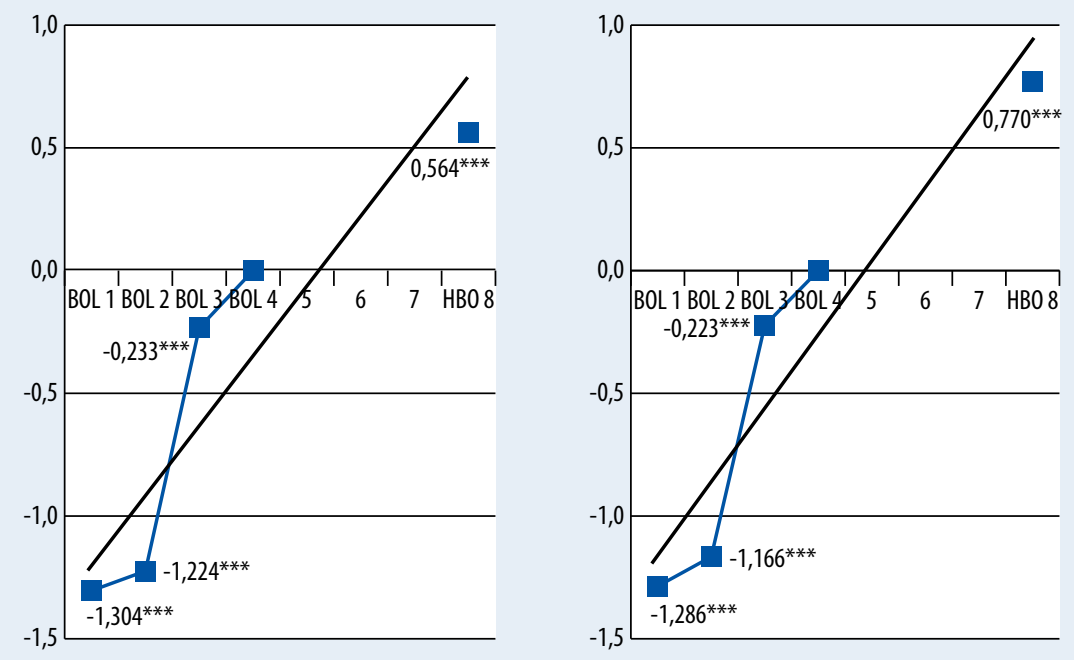

Links: met alle HBO-gediplomeerden, rechts: met alleen HBO-gediplomeerden afkomstig uit het MBO

\subsection{Beloning en carrièremogelijkheden in huidige functie}

In deze paragraaf kijken we naar twee materiële aspecten van arbeidsmarktsucces: de beloning en de carrièremogelijkheden.

\section{Beloning}

Met betrekking tot de beloning in de huidige functie is gekeken naar het bruto uurloon in de huidige functie. Dit als indicator voor de productieve waarde die op de arbeidsmarkt aan betaald werkende schoolverlaters wordt toegekend. Het voordeel boven het bruto maandloon is dat deze indicator niet vervuild wordt door het aantal gewerkte uren. De in figuur 4.I2 gepresenteerde resultaten betreffen overigens reële lonen. Dat wil zeggen nominale lonen die zijn gecorrigeerd op basis van de ontwikkeling van de consumentenprijsindices (inflatie) van het Centraal Bureau voor de Statistiek (op basis van 2009 consumentenprijzen).

Figuur 4.I2 laat duidelijk zien dat het uurloon nagenoeg lineair stijgt met de toename van het opleidingsniveau dan wel het aantal jaren onderwijs. De grootste 'sprongen in beloning' manifesteren zich bij de overgang van $\mathrm{MBO}$ naar HBO. Kijken we naar de positie van BOL niveau 4 opleidingen, dan zien we dat deze precies op de trendlijn ligt, dat wil zeggen het verschil met $\mathrm{HBO}$ bedraagt 4 jaar. Als we alleen de $\mathrm{HBO}$-ers afkomstig uit het MBO meenemen dan komt hetzelfde beeld naar voren. 
Figuur $4.12 a+b$

Lineaire regressieanalyse naar bruto uurloon (in log, met inflatiecorrectie)
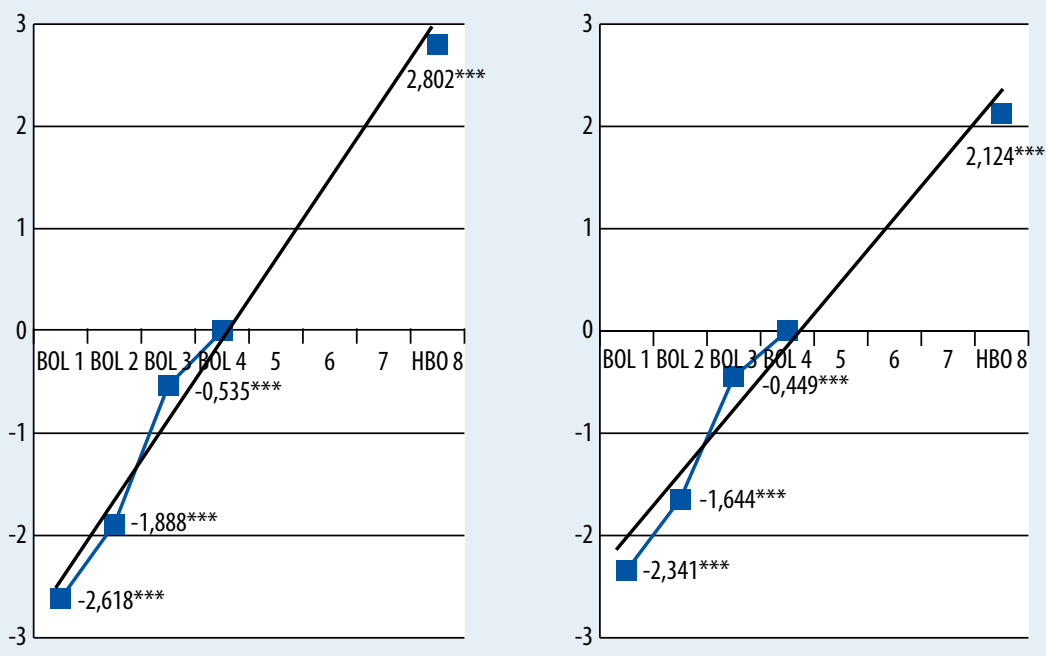

Links: met alle $\mathrm{HBO}-$ gediplomeerden, rechts: met alleen $\mathrm{HBO}$-gediplomeerden afkomstig uit het $\mathrm{MBO}$

\section{Figuur $4.13 a+b$}

Lineaire regressieanalyse naar bruto uurloon van gediplomeerden die minimaal op het eigen niveau werkzaam zijn (in log, met inflatiecorrectie)
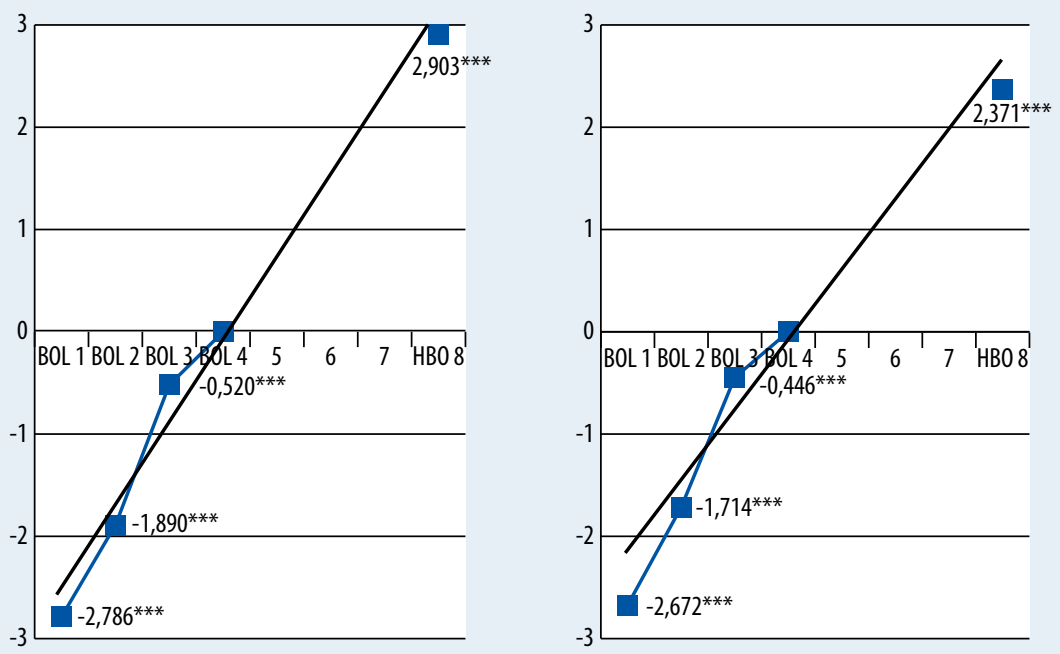

Links: met alle $\mathrm{HBO}-$ gediplomeerden, rechts: met alleen $\mathrm{HBO}-$ gediplomeerden afkomstig uit het $\mathrm{MBO}$ 
Volgens de job matching theorie wordt er alleen een lineair verband tussen jaren onderwijs en uurloon verwacht indien gediplomeerden werkzaam zijn in een baan die aansluit bij hun opleidingsniveau. Daarom hebben we ook een analyse gedaan naar uurloon en daarbij alleen de gediplomeerden die minimaal op hun eigen opleidingsniveau werkzaam zijn meegenomen. De resultaten hiervan zijn figuur 4.I3 weergegeven.

Wat zijn de gevolgen van het selecteren op gediplomeerden die op hun eigen opleidingsniveau werken? Voornamelijk dat de verschillen tussen de opleidingen iets groter worden: vooral BOL niveau I wordt sterker negatief en $\mathrm{HBO}$ wordt sterker positief. Er verandert verder weinig aan het verband tussen jaren onderwijs en uurloon. Dit blijft bijna perfect lineair.

\section{Carrièremogelijkheden in huidige functie}

Een indicatie voor de arbeidsmarktopbrengsten op de lange termijn wordt gevormd door de carrièremogelijkheden die de huidige functie biedt. Op een 5-puntschaal (I 'nauwelijks' <-> 5 'heel veel') konden de betaald werkende schoolverlaters aangeven in hoeverre hun functie goede carrièremogelijkheden biedt. Hun antwoord verschaft een indicatie van de mate waarin de functie die zij circa anderhalf jaar na afstuderen hebben, doorgroeimogelijkheden biedt. In figuur 4.I4 wordt de kans voor betaald werkende schoolverlaters om (heel) veel carrièremogelijkheden in de huidige functie te hebben weergegeven (antwoordcategorie 4 of 5 ).

Figuur 4.14a+b

Logistische regressieanalyse van de kans om in een functie met veel carrièremogelijkheden te werken
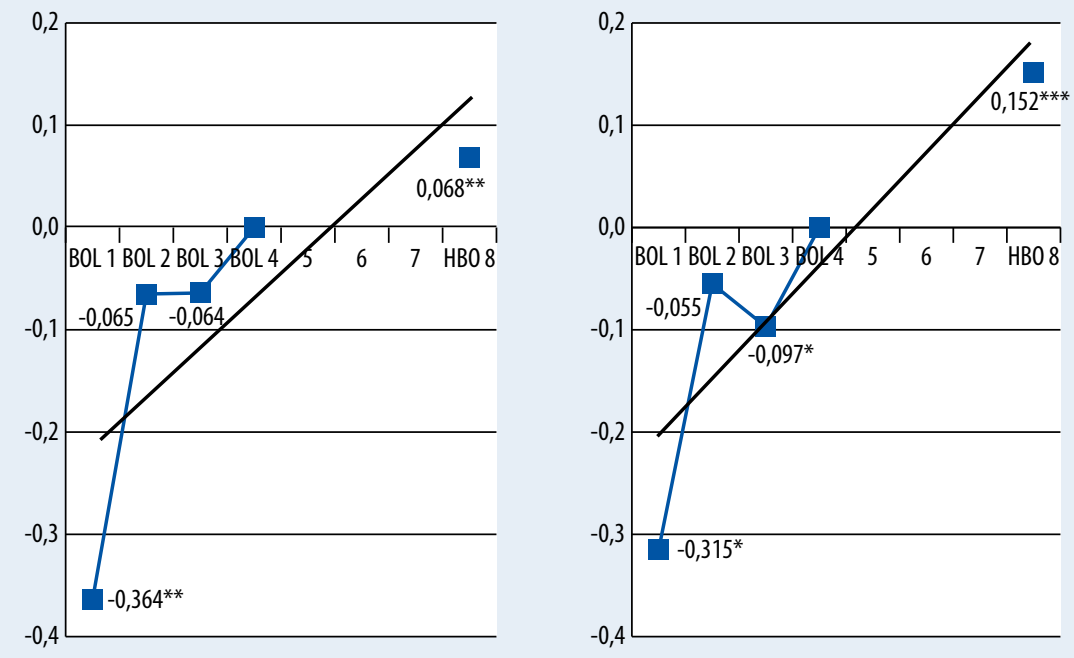

Links: met alle $\mathrm{HBO}$-gediplomeerden, rechts: met alleen $\mathrm{HBO}$-gediplomeerden afkomstig uit het $\mathrm{MBO}$ 
We zien in figuur 4.I9 dat er geen significante verschillen bestaan tussen schoolverlaters van BOL niveaus 2, 3 en 4 wat betreft carrièremogelijkheden in de huidige functie. Wel zien $\mathrm{HBO}$-schoolverlaters significant vaker goede carrièremogelijkheden en BOL-schoolverlaters van niveau I juist significant minder vaak goede carrièremogelijkheden dan schoolverlaters van BOL niveau 4 opleidingen. Vooral de schoolverlaters van het laagste $\mathrm{MBO}$-niveau wijken af van de trend. Het grote verschil hier tussen de niveaus I en 2 benadrukt de waarde van de startkwalificatie voor de carrièremogelijkheden van schoolverlaters. Daarnaast zou men uit de figuur kunnen afleiden dat de schoolverlaters van BOL niveaus 2 tot en met 4 bovengemiddeld goede carrièremogelijkheden in hun huidige functie zien. Voor HBO-schoolverlaters geldt het omgekeerde. Dit wordt echter veroorzaakt door de sterk negatieve waarde voor de BOL niveau I gediplomeerden. Als deze gediplomeerden niet in beschouwing worden genomen bij de analyse dan bevinden de gediplomeerden van de vier overige niveaus zich allemaal op of nabij de trendlijn. Bij de analyse waar alleen $\mathrm{HBO}$-ers met een MBO-diploma zijn meegenomen zitten de resultaten dichter bij de trendlijn. Deze $\mathrm{HBO}$-schoolverlaters zien ruim twee keer zo vaak goede carrièremogelijkheden als de volledige groep $\mathrm{HBO}$-schoolverlaters. Indien wij de schoolverlaters van $\mathrm{BOL}$ niveau I buiten beschouwing zouden laten, liggen de carrière perspectieven van BOL niveau vier precies vier jaar verwijderd van $\mathrm{HBO}$. Opvallend is dat met name BOL niveau 3 achterblijft ten opzichte van BOL niveau 4.

\subsection{Andere arbeidsvoorwaarden}

Om zicht te krijgen op de andere arbeidsvoorwaarden wordt in deze paragraaf gekeken naar de lengte van de werkweek en de de zekerheid van het werk . Daarnaast is gekeken naar de tevredenheid met het werk.

\section{Voltijdwerk in huidige functie}

Het aandeel van betaald werkende schoolverlaters met een voltijdbaan geeft een indicatie van de mate van hun arbeidsparticipatie. Onder een voltijdbaan wordt hier verstaan een baan waarin men voor minstens 33 uur per week betaald werkzaam is. De kans op een voltijdbaan voor de betaald werkende schoolverlaters staat weergegeven in figuur 4.15.

Figuur 4.I5 laat zien dat de kans op een voltijdbaan bijna lineair toeneemt met het opleidingsniveau. De schoolverlaters van BOL niveau 3 en 4 werken iets vaker dan volgens de trendlijn verwacht in voltijdbanen, de schoolverlaters van het $\mathrm{HBO}$ iets minder vaak. Als we alleen rekening houden met $\mathrm{HBO}$-schoolverlaters die uit het $\mathrm{MBO}$ afkomstig zijn dan neemt de kans op een voltijdbaan onder de $\mathrm{HBO}$-schoolverlaters nog verder toe. 


\section{Figuur $4.15 a+b$}

Logistische regressieanalyse van de kans op een voltijdbaan
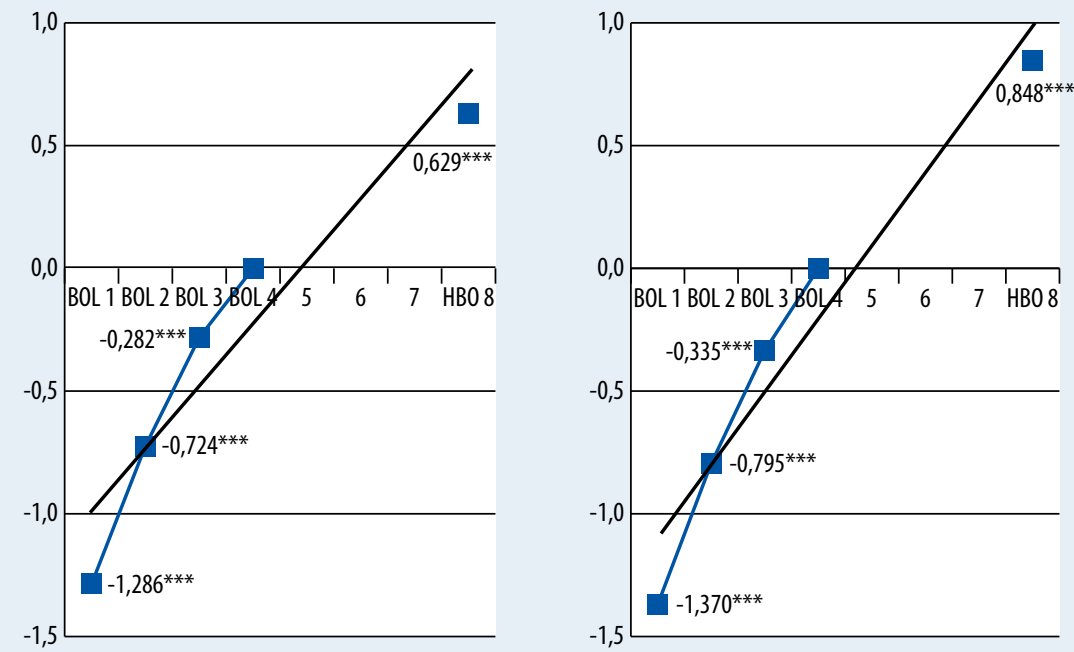

Links: met alle $\mathrm{HBO}-$ gediplomeerden, rechts: met alleen $\mathrm{HBO}$-gediplomeerden afkomstig uit het $\mathrm{MBO}$

\section{Werkzekerheid in huidige functie}

De kans om werk te krijgen is één ding; de zekerheid om het gevonden werk ook te behouden is een ander ding. Figuur 4.I6 laat de resultaten van de analyse van de werkzekerheid zien, dat wil zeggen de analyse van de kans op een vaste aanstelling. Hierbij zijn tijdelijke aanstellingen met uitzicht op een vast dienstverband als tijdelijk beschouwd.

De resultaten in figuur 4.I7 illustreren dat betaald werkende schoolverlaters van BOL niveau 4 opleidingen een even grote kans op een vast dienstverband hebben als betaald werkende schoolverlaters van BOL niveau 3 opleidingen of van $\mathrm{HBO}$ opleidingen. Van een lineair verband tussen jaren scholing en de kans op een vast dienstverband is dus zeker geen sprake.

Overigens vindt de grootste toename van de kans op een vaste baan plaats tussen BOL niveau I en BOL niveau 2. Dit illustreert de waarde van een startkwalificatie op BOL niveau 2. Toch werken schoolverlaters van de niveau 2 opleidingen ook significant minder vaak in een vaste baan dan de schoolverlaters van BOL niveau 4. Nemen we alleen de $\mathrm{HBO}$-schoolverlaters die via het $\mathrm{MBO}$ zijn ingestroomd dan verandert het beeld enigszins. Dan zijn HBO-schoolverlaters significant vaker en schoolverlaters van BOL niveau 3 significant minder vaak werkzaam in een vaste baan dan schoolverlaters van BOL niveau 4. 


\section{Figuur $4.16 \mathrm{a}+\mathrm{b}$}

Logistische regressieanalyse van de kans op een vast dienstverband
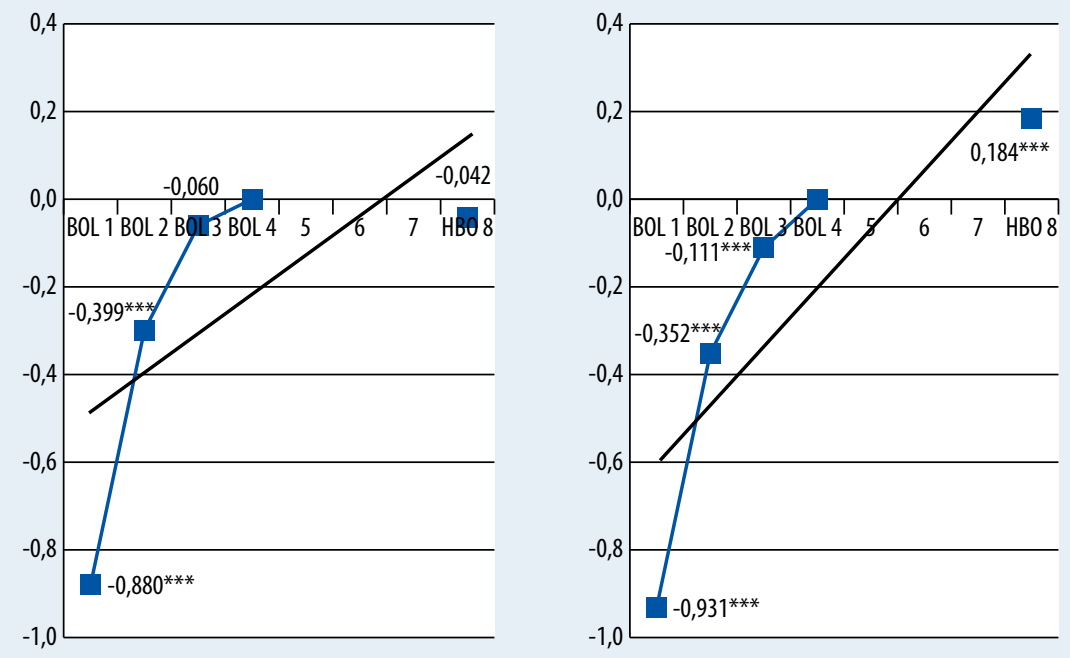

Links: met alle $\mathrm{HBO}-$ gediplomeerden, rechts: met alleen $\mathrm{HBO}$-gediplomeerden afkomstig uit het $\mathrm{MBO}$

\section{Tevredenheid met huidige functie}

De betaald werkende schoolverlaters konden op een 5-puntschaal (I 'zeer ontevreden' <-> 5 'zeer tevreden') aangeven hoe tevreden zij zijn met hun huidige functie (de functie die zij circa anderhalf jaar na afstuderen hebben). De kans voor gediplomeerden om tevreden te zijn met de functie (antwoordcategorie 4 of 5) wordt weergegeven in figuur 4.17.

Uit figuur 4.I7 blijkt dat er nauwelijks een relatie tussen opleidingsniveau en tevredenheid over de huidige functie lijkt te zijn. De meeste opleidingen wijken nauwelijks af ten opzichte van BOL niveau 4 opleidingen. We zien wel een negatieve uitschieter bij de schoolverlaters van BOL niveau 2. Bovendien zijn HBO-schoolverlaters iets vaker tevreden met hun baan anderhalf jaar na het behalen van hun diploma dan de schoolverlaters van BOL niveau 4. Wanneer we alleen de $\mathrm{HBO}$-schoolverlaters met een $\mathrm{MBO}$-vooropleiding meenemen in de analyse leidt dit tot iets grotere verschillen tussen de opleidingen: de $\mathrm{HBO}$-schoolverlaters zijn vaker tevreden over hun huidige functie dan wanneer alle $\mathrm{HBO}$-schoolverlaters worden meegenomen. Opvallend is dat de schoolverlaters van BOL niveau 3 relatief meer tevreden zijn over hun functie dan de schoolverlaters van BOL niveau 4. 


\subsection{Oordelen over de opleiding als basis om te starten op de arbeidsmarkt en zich verder te ontwikkelen}

In aanvulling op de voorgaande indicatoren van arbeidsmarktsucces van schoolverlaters van de verschillende $\mathrm{MBO}$ - en HBO-opleidingen gaan we ook in op het oordeel van de schoolverlaters over hun opleiding (I) als basis om te starten op de arbeidsmarkt en (2) als basis om hun kennis en vaardigheden verder te ontwikkelen. In de enquête konden de schoolverlaters op een 5 -puntschaal (van I 'helemaal niet' $\mathrm{t} / \mathrm{m} 5$ 'in sterke mate') achtereenvolgens aangeven in welke mate hun opleiding een goede basis biedt om te starten op de arbeidsmarkt en voor het verder ontwikkelen van kennis en vaardigheden. In figuur 4.I8 worden de resultaten van de analyse van de kans op een goede voorbereiding op de arbeidsmarkt weergegeven (antwoordcategorie 4 of 5). In figuur 4.I9 doen we hetzelfde voor de analyse van de kans op een goede voorbereiding om zich verder te ontwikkelen.

Schoolverlaters van de BOL niveaus I en 2 vinden hun opleiding significant minder vaak een goede voorbereiding op de arbeidsmarkt dan schoolverlaters van BOL niveau 3 en 4 opleidingen. Onderling is er geen verschil in oordeel tussen de schoolverlaters van niveau I en niveau 2, noch tussen schoolverlaters van niveau 3 en 4 opleidingen. $\mathrm{HBO}$-schoolverlaters oordelen significant vaker positief over de voorbereiding op de arbeidsmarkt die hun opleiding hen verschafte. Als we alleen de HBO-ers afkomstig van het $\mathrm{MBO}$ in de analyse meenemen dan blijkt het verschil met BOL-4 nog iets groter te worden. Met andere woorden: de HBO-schoolverlaters die ook al een MBO-diploma hebben vinden hun opleiding nog vaker een goede voorbereiding voor de arbeidsmarkt dan de andere HBO-schoolverlaters.

Het beeld dat uit figuur 4.I9 naar voren komt is vergelijkbaar met dat uit figuur 4.I8: schoolverlaters van de korte MBO-opleidingen oordelen significant minder vaak dat de opleiding een goede voorbereiding was om zich verder te ontwikkelen dan schoolverlaters van de lange $\mathrm{MBO}$-opleidingen. De $\mathrm{HBO}$-schoolverlaters oordelen juist significant vaker dat hun opleiding een goede voorbereiding voor hun verdere ontwikkeling was en wel bijna precies zoveel vaker als een lineaire trend voorspelt. De analyse waarin alleen de HBO-ers met een MBO-diploma zijn meegenomen levert geen afwijkende resultaten op.

Een voorlopige conclusie is dat op grond van het oordeel over de voorbereiding op de arbeidsmarkt de cesuur ligt tussen de korte en de lange opleidingen in het MBO en tussen de lange opleidingen en het HBO. Het verschil tussen BOL-3 en BOL-4 is vrijwel afwezig als het gaat om de voorbereiding op de arbeidsmarkt, maar is wel iets groter als het gaat over de voorbereiding om kennis en vaardigheden verder te ontwikkelen. 


\section{Figuur 4.17a+b}

Logistische regressieanalyse van de kans om tevreden te zijn met de huidige functie
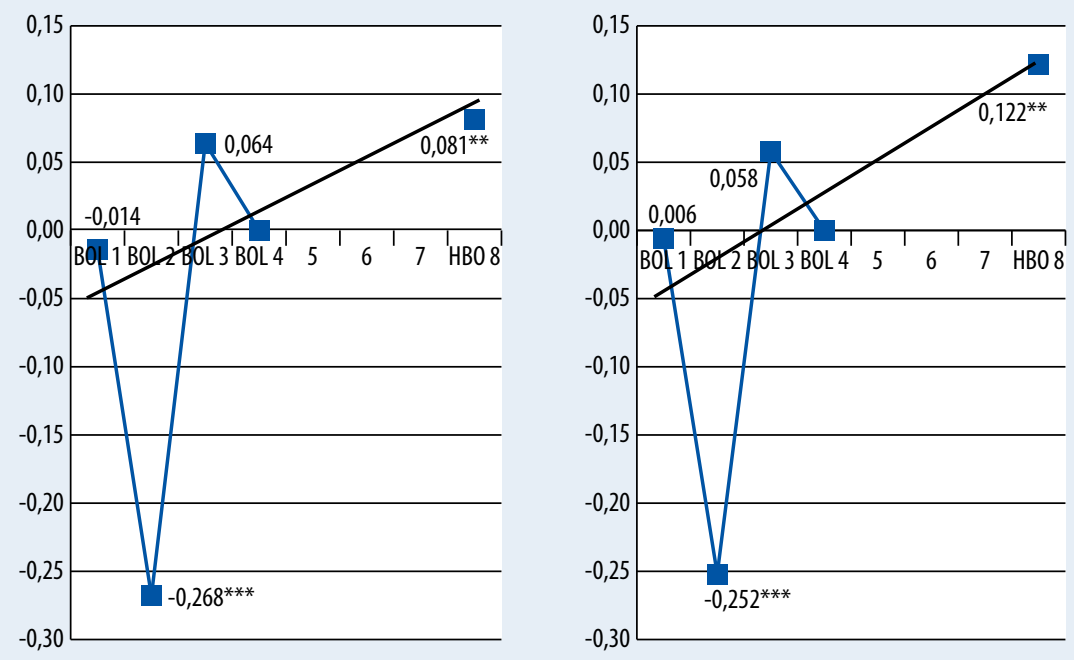

Links: met alle HBO-gediplomeerden, rechts: met alleen $\mathrm{HBO}$-gediplomeerden afkomstig uit het $\mathrm{MBO}$

\section{Figuur $4.18 \mathrm{a}+\mathrm{b}$}

Logistische regressieanalyse van de kans om de opleiding als goede voorbereiding op de arbeidsmarkt te zien
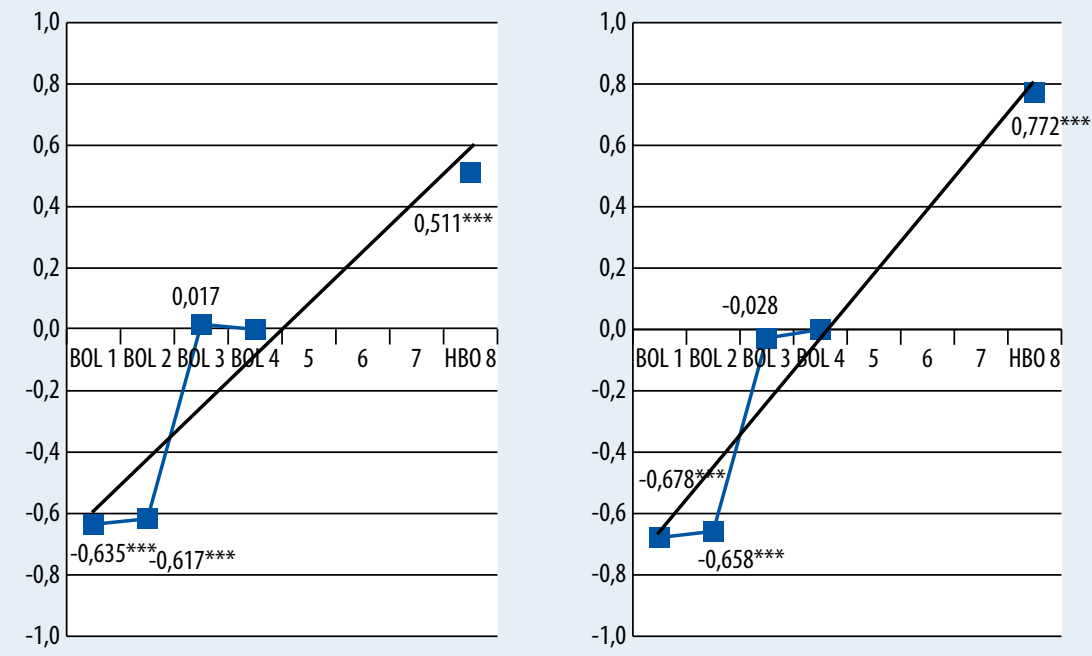

Links: met alle $\mathrm{HBO}$-gediplomeerden, rechts: met alleen $\mathrm{HBO}$-gediplomeerden afkomstig uit het $\mathrm{MBO}$ 


\section{Figuur 4.19a+b}

Logistische regressieanalyse van de kans om de opleiding als goede voorbereiding om hun kennis en vaardigheden verder te ontwikkelen
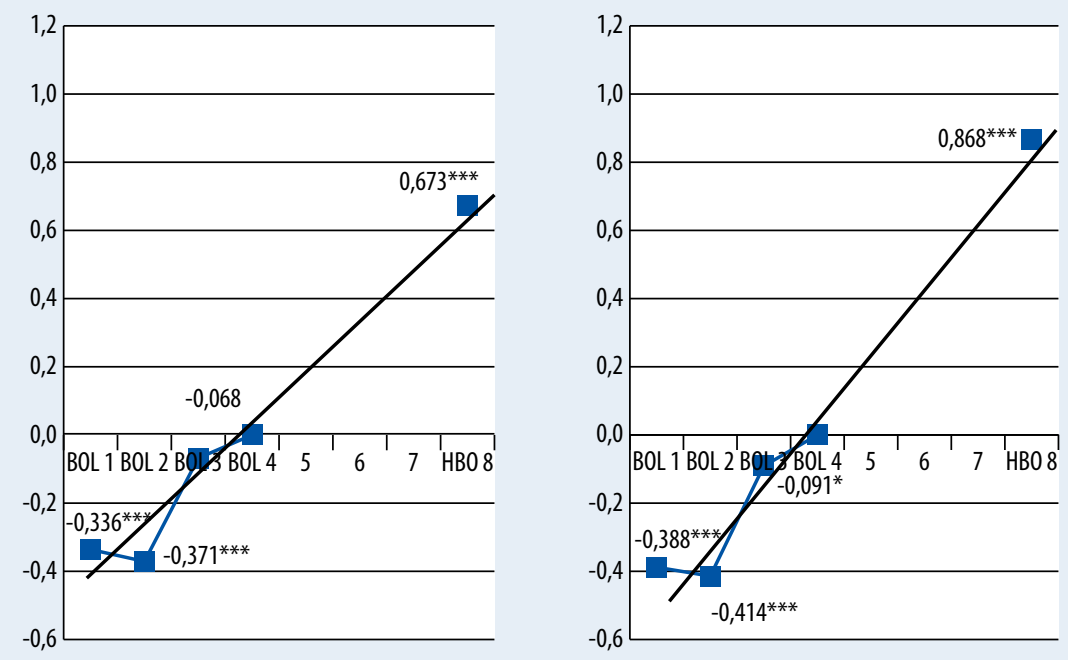

Links: met alle HBO-gediplomeerden, rechts: met alleen HBO-gediplomeerden afkomstig uit het MBO

\subsection{De resultaten op een rij}

Uit de analyses van de opbrengsten van opleidingen is naar voren gekomen dat deze opbrengsten over het algemeen toenemen met het opleidingsniveau, maar dat die toename niet voor elk jaar additioneel onderwijs even groot is. Tabel 4.I presenteert een overzicht van de conclusies met betrekking tot de indicatoren die in dit hoofdstuk zijn geanalyseerd. In de tabel is achtereenvolgens aangegeven tussen welke opleidingsniveaus zich de grootste relatieve verbetering voordoet, en wat de afstand is in jaren tussen $\mathrm{BOL}$ niveau vier en het $\mathrm{HBO}$.

\section{Relatieve verbeteringen in vaardigheden}

De relatieve verbeteringen op het gebied van vaardigheden, in de vorm van CITO entreetoetsscores en IQ zijn min of meer hetzelfde voor elk van de vijf onderscheiden indicatoren. Het verband tussen deze scores en later gevolgd aantal jaren onderwijs is in hoge mate lineair. Het verschil tussen BOL niveau vier en $\mathrm{HBO}$ bedraagt voor elk van de indicatoren 3-4 jaar.

\section{Relatieve verbeteringen in arbeidsmarktopbrengsten}

De grootste relatieve verbetering kan drie keer gelegd worden tussen BOL niveau I opleidingen en BOL niveau 2 opleidingen (zoekduur eerste baan, kans op een vast 
dienstverband en kans op goede carrièremogelijkheden), en vijf keer tussen BOL niveau 2 opleidingen en BOL niveau 3 opleidingen (zoekduur eerste baan, kans op werk, kans op een baan op eigen opleidingsniveau, kans op een baan in de eigen/verwante opleidingsrichting, en kans op een goede voorbereiding voor de arbeidsmarkt).

We concluderen:

- De relatieve verbetering tussen opleidingen op BOL niveau I en opleidingen op BOL niveau 2 is indicatief voor de waarde van een startkwalificatie.

- Dat relatieve verbeteringen zich ook vaak manifesteren tussen BOL niveau 2 opleidingen en BOL niveau 3 opleidingen lijkt erop te duiden dat er ook een zekere cesuur is tussen de korte en lange opleidingen van het $\mathrm{MBO}$.

\section{Relatieve afstand van $\mathrm{BOL}$ niveau 4 opleidingen tot $\mathrm{HBO}$}

Voor iets meer dan de helft van de indicatoren geldt dat de afstand van BOL niveau vier opleidingen tot $\mathrm{HBO}_{3-4}$ jaar bedraagt. Dit geldt voor de vijf indicatoren die het niveau van kennis en vaardigheden illustreren op twaalfjarige leeftijd (CITO-entree toetsen en IQ ), alsmede voor vier arbeidsmarktindicatoren: bruto uurloon, kans op een voltijdbaan, de kans dat de opleiding een goede voorbereiding biedt om te starten op de arbeidsmarkt en de kans dat de opleiding een goede voorbereiding biedt voor de verdere ontwikkeling van kennis en vaardigheden. Bij drie arbeidsmarkt indicatoren bedraagt het verschil slechts 2-3 jaar: dit geldt voor de kans op werk, de kans op een baan in de eigen of verwante opleidingsrichting en de kans op een baan met goede carrièremogelijkheden. Voor de resterende indicatoren geldt dat het verband onduidelijk is of dat het HBO het zelfs slechter doet dan BOL-4. Dit geldt voor zoekduur tot de eerste baan, de kans om een baan te hebben op het eigen opleidingsniveau, de kans op een vast dienstverband en de tevredenheid met de functie.

Tabel 4.1

Samenvatting belangrijkste onderzoeksresultaten

\begin{tabular}{|c|c|c|}
\hline Indicator & $\begin{array}{l}\text { Grootste relatieve toenames } \\
\text { van ... naar ... }\end{array}$ & $\begin{array}{l}\text { Afstand } \mathrm{BOL}-4 \text { naar } \mathrm{HBO} \text { in } \\
\text { jaren }\end{array}$ \\
\hline Vaardigheden (5keer) & Volgens trend & 3-4 jaar \\
\hline Zoekduur eerste baan & $\begin{array}{l}\mathrm{BOL} 1 \rightarrow \mathrm{BOL} 2 \\
\mathrm{BOL} 2 \rightarrow \mathrm{BOL} 3\end{array}$ & Geen (HBO doet het slechter) \\
\hline Kans op werk & $\mathrm{BOL} 2 \rightarrow \mathrm{BOL} 3$ & $2-3$ jaar \\
\hline Kans op een baan op eigen opleidingsniveau & $\mathrm{BOL} 2 \rightarrow \mathrm{BOL} 3$ & Geen (HBO doet het slechter) \\
\hline Kans op een baan in de eigen of verwante opleidingsrichting & $\mathrm{BOL} 2 \rightarrow \mathrm{BOL} 3$ & $2-3$ jaar \\
\hline Bruto uurloon & Volgens trend & 4 jaar \\
\hline Kans op goede carrièremogelijkheden & $\mathrm{BOL} 1 \rightarrow \mathrm{BOL} 2$ & $2-3$ jaar \\
\hline Kans op een voltijdbaan & Volgens trend & 3 jaar \\
\hline Kans op een vast dienstverband & $\mathrm{BOL} 1 \rightarrow \mathrm{BOL} 2$ & Geen (HBO gelijk) \\
\hline Kans op tevredenheid met functie & Niet lineair & Geen verband \\
\hline Kans op goede voorbereiding op arbeidsmarkt & $\mathrm{BOL} 2 \rightarrow \mathrm{BOL} 3$ & 3-4 jaar \\
\hline Kans op goede voorbereiding voor verdere ontwikkeling & Volgens trend & jaar \\
\hline
\end{tabular}





\section{Conclusie}

In dit onderzoek hebben we een analyse gemaakt van de positie van de Nederlandse MBO-4 opleidingen. Gekeken is of afgestudeerden van de BOL niveau vier opleidingen qua vaardigheden en succes op de arbeidsmarkt gerekend zouden moeten worden tot het $\mathrm{HBO}$, of dat ze toch typisch tot het $\mathrm{MBO}$ moeten worden gerekend. Hiervoor zijn de uitkomsten van verschillende indicatoren voor schoolverlaters van de MBO-BOL opleidingen vergeleken met de naast lager en hoger gelegen beroepsopleidingen in het $\mathrm{MBO}$ en $\mathrm{HBO}$.

Als we kijken naar die indicatoren die het meest direct het menselijk kapitaal weerspiegelen (dat zijn de scores op de CITO entree toetsen, het IQ en de beloning in de huidige functie), dan lijkt de positie van BOL niveau vier precies overeen te komen met wat op grond van de cumulatieve opleidingsduur voorspeld zou worden: ongeveer een jaar verwijderd van BOL niveau drie en ongeveer 3-4 jaar verwijderd van $\mathrm{HBO}$.

Voor alle andere indicatoren geldt dat er niet altijd theoretische gronden aanwezig zijn om een lineair verband te veronderstellen. Voor sommige van deze indicatoren geldt eveneens een afstand van 3-4 jaar tot het HBO (bijvoorbeeld voor de zoekduur tot de eerste baan en de oordelen of de gevolgde opleiding een goede basis biedt om te starten op de arbeidsmarkt en voor de verdere ontwikkeling van kennis en vaardigheden), maar voor andere indicatoren geldt dat de afstand kleiner is of zelfs nihil.

De bevindingen geven geen aanleiding om $\mathrm{MBO}$ niveau 4 tot het hoger onderwijs te rekenen in de Nederlandse institutionele context. Daarmee is echter de vraag naar de internationale positie van mbo-4 nog niet beantwoord.

Uit de analyses komt ook nog een aantal andere bevindingen naar voren die van belang zijn.

I. BOL niveau I opleidingen bieden duidelijk geen volwaardige startkwalificatie. Dit uit zich in veel slechtere arbeidsmarktopbrengsten voor deze groep, met name in een lange zoekduur tot de eerste baan, een lagere kans op een vast dienstverband en minder goede carrièremogelijkheden. Het lijkt erop dat een groot deel van deze gediplomeerden aangewezen is op de nietspecifieke deelmarkten. 
2. Voor een groot aantal indicatoren geldt dat er ook een duidelijk verschil is tussen de korte opleidingen (BOL I en 2) en de lange opleidingen in het MBO (BOL 3 en 4 ) in termen van arbeidsmarktsucces. Dit geldt voor de kans op werk, de kans om een passende baan te vinden en het oordeel of de opleiding een goede basis biedt om te starten op de arbeidsmarkt. Dit zou kunnen impliceren dat het niveau dat vereist is om succesvol te kunnen functioneren op de arbeidsmarkt eigenlijk bij BOL niveau 3 ligt in plaats van bij BOL niveau 2. We zouden ons dan ook de vraag kunnen stellen of BOL niveau 2 nog wel het etiket 'startkwalificatie' verdient. 


\section{Literatuur}

Becker, G.S. (1964), Human capital: a theoretical and empirical analysis with special reference to Education, NBER, New York.

Hartog, J. (1992), Capabilities, Allocation and Earnings, Kluwer Academic Publishers, Boston/ Dordrecht/London.

Hartog, J. (2000), 'On returns to education: wandering along the hills of oru land', in: Heijke, H. \& J. Muysken (red.), Education and training in a knowledge-based economy, MacMillan Press, Houndsmills.

Jovanovic, B. (1979), Job matching and the theory of turnover, Journal of Political Economy, Vol. 87, nr 5, pp 972-990.

Lutz, B. \& W. Sengenberger (1974), Arbeitsmarktstrukturen und öffentliche Arbeitsmarktpolitik, Otto Schwartz \& Co., Göttingen.

Researchcentrum voor Onderwijs en Arbeidsmarkt (1999), Schoolverlaters tussen onderwijs en arbeidsmarkt 1998, ROA, Maastricht.

Researchcentrum voor Onderwijs en Arbeidsmarkt (2003), De arbeidsmarkt naar opleiding en beroep tot 2008, ROA, Maastricht.

Sattinger, M. (1975), Comparative advantage and the distribution of earnings, Econometrica, Vol. 43, nr. 3, pp 455-468.

Sattinger, M. (1993), Assignment Models of the Distribution of Earnings, Journal of Economic Literature, nr. 31, pp 831-880.

Thurow, L.C. (1975), Generating inequality, Basic Books, New York.

Velden, R. van der, R. de Vries, M. Wolbers \& P. van Eijs (2002), De waarde van een startkwalificatie, ROA, Maastricht. 
